Boise State University

ScholarWorks

$10-1-2015$

\title{
Intergenerational Effects of Disability Benefits: Evidence from Canadian Social Assistance Programs
}

Kelly Chen

Boise State University

Lars Osberg

Dalhousie University

Shelley Phipps

Dalhousie University 
This is an author-produced, peer-reviewed version of this article. The final, definitive version of this document can be found online at Journal of Population Economics, published by Springer. Copyright restrictions may apply. doi: 10.1007/s00148-015-0557-9

\title{
Intergenerational Effects of Disability Benefits: Evidence from Canadian Social Assistance Programs
}

\author{
Kelly Chen \\ Department of Economics \\ Boise State University \\ Boise, Idaho \\ Lars Osberg \\ Department of Economics \\ Dalhousie University \\ Halifax, Nova Scotia, Canada \\ Shelley Phipps \\ Canadian Institute for Advanced Research, and \\ Department of Economics \\ Dalhousie University \\ Halifax, Nova Scotia, Canada
}

\begin{abstract}
Individuals with disabilities face greater challenges in the labor market than able-bodied individuals and a growing body of research is finding that their children also tend to have more developmental problems than the children of able-bodied parents. Can transfer payments help reduce this gap? In this paper, we present the first evidence on how parental disability benefits affect the well-being of children. Using changes in real benefits under ten disability benefit programs in Canada as an identification strategy and Statistics Canada's National Longitudinal Survey of Children and Youth (NLSCY) as the data source on child outcomes, we find strong evidence that higher benefits lead to improvements in children's cognitive and non-cognitive development, as measured by math scores in standardized tests, hyperactive symptoms and emotional anxiety behavior. The effect is larger on children with a disabled mother than on those with a disabled father.
\end{abstract}

JEL Codes J1 J6 I38

Keywords: disability benefits, child well-being, welfare, intergenerational transmission 
This is an author-produced, peer-reviewed version of this article. The final, definitive version of this document can be found online at Journal of Population Economics, published by Springer. Copyright restrictions may apply. doi: 10.1007/s00148-015-0557-9

\section{Introduction}

In most Statistics Canada's population surveys, disability is defined as being functionally limited in usual activities due to a health related problem or condition for more than six months. ${ }^{1}$ Based on this definition, an estimated 2.4 million working-age Canadians (11.5 \% of total population) reported at least one disability in 2006 (Human Resources and Social Development Canada, 2009). Within this large population, many are parents of children under 15. Using data from the National Longitudinal Survey of Children and Youth (NLSCY), we estimate around 1.8 million Canadian children aged under 15, about one in six, lived with at least one disabled parent at a point in time during 1994-2006. Based on Census 2000 for the U.S. and a measure of more serious disabilities, Avery and Hogan (2006) report that about $13 \%$ of non-disabled children aged 5-17 grow up in families with at least one disabled parent. Parental disability thus is a considerable influence in the lives of many young and adolescent children. ${ }^{2}$

The importance of parental investment to the healthy development of children has been noted by a large literature in economics. However, maintaining the optimal level of investment may be especially difficult for parents with disabilities. A growing body of research has found that children living with a disabled parent fare significantly worse than children of non-disabled parents in school enrollment (Mont and Cuong 2013; Bratti and Mendola 2014), educational attainment (Haveman and Wolfe 1995), and behavioral problems (Morefield 2010; Morefield, Mühlenweg and Westermaier, 2011). Importantly, the evidence is not only found in developing countries, but also within societies, such as Germany, with well-developed social safety nets and substantial intergenerational mobility. ${ }^{3}$

The policy question is whether more income, in particular, government transfers to poor parents with disabilities, can help mediate the negative consequences of parental disability and improve children's well-being. The consensus of a large literature studying implications of family income for child outcomes is that current income has a relatively small association with child outcomes (Currie 2008 and 2011; Currie and Stabile 2003; Dooley and Stewart 2004; Mayer 1997; Mayer and Jencks 1993). However, the situation for children in families with disabled parents may be somewhat different. First, the marginal value of income may be larger since families with disabled parents have both lower incomes and higher expenses (e.g., medical or potentially for domestic help, depending on the nature and severity of the condition). Also, the marginal value of time at home for the non-disabled parent may be higher, given that the nondisabled parent will likely face a larger share of standard childcare and housework as well as potentially increase care required by the individual with the disability.

In this paper, we present the first evidence on how parental disability benefits can affect the development of young children. We draw data from Statistics Canada's National Longitudinal Survey of Children and Youth (NLSCY), a nationally representative survey that provides intergenerational information on parents and children, including both parents' activity limitations. We focus on three outcomes that are commonly perceived as key elements of children's human capital: cognitive ability, behavioral problems and social/emotional well-being, as measured by math scores in

\footnotetext{
${ }^{1}$ For example, Statistics Canada's Participation and Activity Limitation Survey (PALS) identifies persons with a disability by using two filter questions on the Census. The first question asks the respondents whether they have any difficulties in hearing, seeing, communicating, walking, climbing stairs, bending, learning or doing any similar activities. The second question asks whether there are any physical/mental conditions or health problems that reduce the amount or kind of activity the person can do at home, in leisure activities, at work, or at school. A yes to any of these questions will result in a respondent being selected into the PALS survey pool.

${ }^{2}$ Documentation on the prevalence of parents with disabilities has been extremely scarce in the literature. A main reason may be data availability -- most national surveys provide information on the number of people with disabilities or the number of parents, but not the combination of these two characteristics (Preston 2012).

${ }^{3}$ For example, Mont and Cuong (2013) find in the 2006 Vietnam Household Living Standards Survey that children of parents with a disability have a lower enrollment rate in primary and secondary school. Bratti and Mendola (2014) presents evidence from the Bosnia and Herzegovina (BiH) Living Standards Measurement Survey (LSMS) that children of mothers with severe limitations in activity of daily living are less likely to be in school at ages 15-24. Morefield, Mühlenweg and Westermaier (2011) find from the German Socio-Economic Panel (GSOEP) that worklimiting disabilities of either parent significantly increase children's problem behaviours and negatively affect their personality traits.
} 
This is an author-produced, peer-reviewed version of this article. The final, definitive version of this document can be found online at Journal of Population Economics, published by Springer. Copyright restrictions may apply. doi: 10.1007/s00148-015-0557-9

standardized tests, parent-report hyperactive symptoms and emotional anxiety behavior, all of which have been shown to have lasting implications for children's educational attainment and eventual labour market success (Cameron and Heckman 1998; Cunha, Heckman and Schennach 2010; Currie and Almond 2011).

In Canada, needs-tested disability benefits are provided by provincial governments. In administering their own programs, each province has the flexibility of setting up its own rules and benefit levels, resulting in considerable variation in benefit generosity both across provinces and over time. For example, as shown in Table 1, in 1994 Ontario (at $\$ 15,338$ ) had substantially higher benefits than Quebec (at \$10,468). Subsequently, Ontario cut its benefits substantially (by $19 \%$ during our observation period) while Quebec kept its rates roughly constant. In 2000, New Brunswick offered even less than Quebec $(\$ 8,337)$ while an individual with the same disabling condition in Ontario was entitled to $\$ 14,101 .{ }^{4}$

In this study, we consider these changes in real benefits under ten disability benefit programs to be a source of exogenous variation, and use a continuous difference-in-differences (DD) approach to investigate the effect of parental disability benefits on child's development assuming that the child's province of residence, hence exposure to variation in benefit levels is independent of the unobservable determinants of the child's outcomes. Because unmeasured withinprovince shocks may influence all children's outcomes, ${ }^{5}$ we use children of non-disabled parents who live in the same province as comparison group and test whether changes in the outcomes gap between children with disabled and nondisabled parents correspond to the changes in benefits within provinces over time. Since social assistance benefits are only relevant for lower-income households, our main analysis restricts the sample to children whose both parents have low education.

If the benefit claim, benefit duration or the incidence of self-reported disability is influenced by the generosity of benefits, or if there is an inter-provincial migration response to benefit changes, then our identifying assumption may, in principle, be violated. The richness of the NLSCY allows us to address these sources of bias by constructing a longitudinal sample that tracks each child over time.

In every province, there is an achievement gap between the children of disabled and non-disabled parents, but we find that the gap is smaller when disability benefits are higher. Overall, we conclude that higher parental disability benefits lead to a substantial reduction in the gap in cognitive and non-cognitive skill development between children of disabled and non-disabled parents. We know of no plausible argument why greater benefits paid to disabled parents should diminish achievement among the children of non-disabled parents - hence our interpretation is that the gap narrows because the achievement of children of disabled parents is improved. The intention-to-treat (ITT) estimates of this paper suggest that children with disabled parents living in a province that cut its real annual disability benefits by $\$ 3,000$, as Ontario did during 1994--2008, would experience a decrease of $3 \%$ of one standard deviation in cognitive ability as measured by standardized math test scores and 10-11 \% of one standard deviation increase in behavior problems and emotional anxiety. According to a crude extrapolation based on available data, we assess the magnitude of the treatment effect (i.e. the average treatment on the treated) to be 6-7 times as large as the ITT effect found in this paper.

We find different benefit effects depending on the gender of the disabled parent: lower benefits result in a significant detrimental effect for children with a disabled mother but not for children with a disabled father. All things being equal, a $\$ 1,000$ benefit reduction leads to a $2 \%$ of a standard deviation reduction in math test scores, and a $6 \%$ and $4 \%$ standard deviation increase in behavior problems and emotional anxiety for children who have a disabled mother. Our preliminary analysis on mechanisms suggests one channel through which lower benefits may hurt children is the non-disabled spouse's time inputs - when the mother is disabled, her effective time devoted to childcare can be low, so fathers' time spent with children may be particularly important. Our finding is also consistent with the "good mother hypothesis" (e.g. Lundberg, Pollak and Wales 1997; Phipps and Burton 1998; Woolley 2004) that a mother's income is more likely than a father's income to be spent in ways that benefit the children.

\footnotetext{
${ }^{4}$ All dollar values expressed in 2008 dollars.

${ }^{5}$ For example, Milligan and Stabile (2011) using data from the Canadian NLSCY conclude that the provincial child tax benefit policies initiated in 1998 have a significant positive effect on educational outcomes, physical health and mental health for the general population of children.
} 
This is an author-produced, peer-reviewed version of this article. The final, definitive version of this document can be found online at Journal of Population Economics, published by Springer. Copyright restrictions may apply. doi: 10.1007/s00148-015-0557-9

Numerous researchers have examined the labor market disincentive effects of disability benefit programs (e.g. Bound and Burkhauser 1999; Haveman and Wolfe 2000; Campolieti 2004; Campolieti, Gomez and Gunderson, 2009), our study is the first to investigate the implication of disability benefits for the development and well-being of children. Our study also differs from many existing studies on welfare and child development by focusing on a vulnerable group of children who have thus far been largely ignored by economists (i.e. children with a disabled parent), and by including not only indicators of cognitive skills (i.e. math test scores), but also non-cognitive skills (i.e. children's problem behaviour and emotional well-being). Finally, our family income and parental employment analysis contributes to a broader economics literature on the labour supply effects of disability benefits. Our estimates of disability benefit effects on weekly hours of work fall roughly within the range of previously published estimates using Canadian data, and are consistent with the "missing added worker" effects found by other studies in North America (e.g. Colie 2004; Gallipoli and Turner 2009).

The remainder of the paper is laid out as follows: Section 2 discusses relevant literature and discusses some conceptual issues to guide the subsequent empirical analysis; Section 3 introduces provincial disability benefit programs; Section 4 and 5 describe our empirical strategy and datasets. Sections 6 and 7 present the results and conclude, respectively.

\section{Parental Money, Time and Children’s Well-Being}

Despite strong evidence that living with a disabled parent significantly impairs the development of children, very little is known about the extent to which increased parental income can improve the outcomes. In fact, there has been a long-standing debate in the economics literature over the nature, as well as the size of the relationship between parental income and the well-being of children (see a comprehensive review by Mayer 1997). In theory, the economic models that originate from Becker and Tomes (1986) clearly make the case that children's well-being depends upon investment decisions made by their parents. How much parents invest in their children is constrained by their ability to finance investment - i.e. by their income and access to capital. Yet many studies find small and sometimes even statistically insignificant associations, depending on the measure of income and the component of children's well-being studied.

A number of recent studies suggest that the economic resources of parents can be multi-dimensional in nature, and annual money income flows alone may not capture all channels through which a parent's deprivation and/or poverty status can hurt children. For example, using housing as a proxy for family assets and data from the Statistics Canada's NLSCY, Curtis and Phipps (2000) find that after controlling for current and/or long-run average family income, children who live in owner-occupied housing have better outcomes than children who do not, and children who live in housing in need of major repairs have worse outcomes. Their research also indicates that holding income constant, more hours of parental time available each week ${ }^{6}$ significantly improves a child's success at school. Using the U.S. National Longitudinal Survey of Youth (NLSY), Ruhm (2004) finds that conditional on income levels, maternal employment, as measured by weekly work hours, during the first years of the child's life has a large deleterious impact on the math and reading performance of young children. If true, the policy implication of these findings is that, besides the income transfer itself, government income transfer programs may have an additional relationship with child wellbeing if they assist families with children to accumulate assets such as housing, or if they increase parental time spent with children.

The impact of government income transfers on children can be further complicated by the design of a transfer program. The evidence from existing literature on the effect of various welfare programs on children in general is rather mixed (Currie 1998). One difficulty in establishing the causal effect of transfer incomes on children's outcomes is that welfare transfers can create incentives for parents to modify their behaviors. As explained in Moffit (1992), these behavioral responses might have additional adverse or positive consequences on children, and they might strengthen or dampen the effects of the transfers themselves. For example, a higher benefit rate can create labor market disincentives for poor parents, leading to lower employment and employment income. It can also facilitate poor parents transitioning from welfare to employment or moving from unstable, low-skilled jobs to relatively "better" ones. In this case, future employment income is likely to increase as a result. The a priori directions of associations between benefit rates and family income are thus unclear, and the effect of transfers may depend on the nature of the parents' employment.

\footnotetext{
${ }^{6}$ In this paper, they measure the hours of parental time available for children as total weekly hours less "sleep time", less weekly hours of paid work. They argue that weekly rather than annual hours are more relevant for children, since care cannot be deferred until a later point in the year. See also Phipps, Burton and Osberg (1996) who find it is weekly hours which generate most time stress for adults.
} 
This is an author-produced, peer-reviewed version of this article. The final, definitive version of this document can be found online at Journal of Population Economics, published by Springer. Copyright restrictions may apply. doi: 10.1007/s00148-015-0557-9

Studies of U.S. welfare reforms have found maternal employment effects that are favourable for child development only when mothers voluntarily chose employment, when they are employed in stable jobs that provide supportive working environments, or when maternal employment results in substantially increased family income (i.e. if jobs pay more than US\$5.00 per hour) (Alessandri 1992; Moore and Driscoll 1997; Miller and Zhang, 2007). In the Canadian context, Morris and Michalopoulos (2000) use data from the Canadian Self-Sufficiency Project (SSP), a program that offered welfare recipients the opportunity to receive an income supplement if they obtained full-time employment. They find that increased maternal employment results in more problematic behaviour for adolescents, despite of increases in family incomes. ${ }^{7}$

Relative to the general population of children, there are a number of reasons to expect that income transfers may be more important for children living with a disabled parent. First, many studies on the income gradient of child outcomes indicate that improvements in parental income at low level have larger developmental gains for children, especially when the income is measured as long-term family resources or "permanent income" (Blau 1999; Curtis, Dooley, Lipman and Feeny 2001). Even if there are diminishing marginal returns to income transfers, people with disabilities are often considered as "the poorest of the poor", and therefore can be expected to have the largest marginal return.

Compared with able-bodied parents, parents with disabilities are not only at greater risk of having low income but also of persistent low income. Galarneau and Radulescu (2009), using data from the Canadian 1994-2006 Survey of Labor and Income Dynamics (i.e. roughly the same time frame as the data used in current study), find that workingage Canadian men disabled for two to five years had twice as high a risk, and those disabled for six years had eight times the risk of men without a disability; Canadian women disabled for six years were at four times a higher risk than non-disabled women. On top of the limited earnings capacity, they may face additional financial costs due to the health problems. Doctor or hospital bills are not an issue in Canada, but many other expenses are not covered by public health insurance (e.g. wheelchair ramps, hearing aids, travel from a rural area to visit specialists in the city, or "deductibles" on drugs) see Burton, Chen, Lethbridge and Phipps (2014).

Second, for families with a disabled parent, transfer income often represents a significant portion of the family budget, and thus may have more direct and immediate influence on maintaining basic living standards of the household than is the case in families with able-bodied parents. The Federal Disability Report indicates that $37 \%$ Canadians with disabilities claimed government transfer as their primary source in 2006, whereas the corresponding figure for persons without disabilities is $11.9 \%$. Overall, persons with disabilities were over three times more likely to receive government income supplement compared to their counterparts without disabilities (HRSDC 2009).

Third, families with disabilities often also face greater barriers to the cross-spouse substitution of parental hours in child care. In contrast to the traditional gender role within household proposed by "identity model" (Akerlof and Kranton, 2000), recent research on spousal care-giving suggests that the presence of a parent with a disability may shift the gendered division of care in the family (Gordon and Perrone 2004; Hogan, Shandra and Msall 2007; Mann and Dieppe 2006; Beauregard and Noreau 2009). The additional demands on time and energy related to having a partner with a disability may exacerbate caregiver burden and affect other family roles and responsibilities. Because mothers are often responsible for most of the care-giving and domestic labor in the family, the presence of a father figure with a disability may place additional strain on a mother's ability to provide family resources. Conversely, when a mother is disabled, a father may assume greater child-care responsibilities such as getting involved in home learning activities, participating in school programs, or supervising their children's after-school activities, thus becoming the effective care-giver. These responses make sense as a household coping strategy. However it also implies that by pushing the non-disabled spouse to work, thereby reducing his or her time spent participating in activities with the child, inadequate income support can impair the parents' ability to provide a positive developmental environment for children.

\footnotetext{
${ }^{7}$ According to this study, most mothers do not place their adolescent children in structured care after school as they did with their younger children. Adolescents may have difficulties if left alone after school and into the evening hours as mothers take on off-hours and shift work. They also find adolescent children may be asked to take on greater household responsibilities and may be encouraged to engage in employment themselves when their single mothers move into employment. While there is limited research on the effects of household chores on children, a high level of employment during adolescence (particularly more than 20 hours of employment) has been linked with children's difficulties in school and increased drug and alcohol use.
} 
This is an author-produced, peer-reviewed version of this article. The final, definitive version of this document can be found online at Journal of Population Economics, published by Springer. Copyright restrictions may apply. doi: 10.1007/s00148-015-0557-9

\section{Provincial Disability Benefit Programs}

In Canada, provincial disability benefits are delivered either through the disability component of social assistance programs (Newfoundland and Labrador, Nova Scotia, New Brunswick, Quebec, Manitoba, Saskatchewan and British Columbia) or through disability support programs that specifically target the disabled (Ontario, Alberta and $\mathrm{PEI}^{8}$ ). Combined, these benefits constitute the second largest income support program for the disabled next to the Canada / Quebec Pension Plan (C / QPP) disability benefits. ${ }^{9}$

Provincial disability benefits provide needs-tested income assistance for people with disabilities who are either ineligible for other benefits or for whom other benefits received are inadequate (e.g. C / QPP disability benefits, the Guaranteed Income Supplement, the Spouse's Allowance, Allowance for the Survivor, or War Veterans Allowance). Eligibility for provincial programs includes a needs-test and a work limiting disability. Given that an applicant family's liquid and fixed assets from non-exempted sources do not exceed the maximum allowable levels, ${ }^{10}$ disability benefits are offset dollar-for-dollar with unearned income (e.g. interest income, pensions, or other needs-tested transfer income) and earned income that is not exempt. ${ }^{11}$ During our study period, only one province changed its basic earnings exemption level, ${ }^{12}$ and importantly, neither earnings exemption nor asset limits in any of the provincial programs is indexed for inflation.

Besides the requirements on income and assets, each provincial program also makes benefits conditional on an assessment of disability, using its own definition of disability. ${ }^{13}$ As shown in Appendix Table 1, however, the designation of disability is similar across provinces in the sense that: (1) all provincial programs require applicants to submit a medical certificate completed by a licensed physician indicating the level of the impairment and the potential for rehabilitation; (2) all provinces also require that the disability must have a substantial impact on the potential recipient's usual activities, and has to occur on a continuous or recurrent basis (e.g. last for at least 3-12 months).

Disability benefits under every provincial program consist of a basic allowance intended to cover the cost of food, clothing, utilities, personal and household items, and a shelter allowance that covers rent or mortgage. Some provincial programs also provide extra benefits to meet special needs such as drug and dental coverage, vision care, medical transportation, diabetic supplies, assistive devices and mobility device repairs and batteries. Prior to 1996, the federal government funded $50 \%$ of the benefits for all provincial programs through the Canada Assistance Plan (CAP), which offered a matching grant for provincial spending. Following 1996, a block grant (the Canada Health and Social Transfer - CHST) replaced CAP, resulting in substantial reduction in the federal government's contributions. In order to accommodate the cuts in federal support, provinces enacted a variety of changes, reducing welfare benefit levels,

\footnotetext{
${ }^{8}$ The disability support program in PEI provides income support to persons with disabilities on a case-by-case base. In this study, we use data on PEI's social assistance program. Alberta also has a distinct program for persons with disabilities: the Assured Income for the Severely Handicapped (AISH) program. Different from other provincial disability benefit programs, the AISH clients are provided with a flat rate living allowance benefit which is not contingent on family size. We replicate our analysis later with children from these two provinces excluded. As are shown, our main results are not substantially affected.

${ }^{9}$ In 2001, of the 3.42 million adults with disabilities in Canada, $10 \%$ received income support from provincial disability benefit programs, about the same proportion as those receiving a Canadian / Quebec Pension Plan (Prince 2008).

${ }^{10}$ All provincial programs exempt most fixed assets, such as principal residence, vehicles (up to a certain limit), the value of prepaid funerals and property/equipment required for employment, while liquid assets are only partially exempt.

${ }^{11}$ All provincial programs exempt a portion of employment income although using slightly different formulae. For example, Nova Scotia allows its client families to keep the first $\$ 200$ of earned total income and one-fourth of earnings exceeding \$200 per month.

${ }^{12}$ PEI increased its basic earnings exemption level from $\$ 600$ to $\$ 900$ per month in 2001.

${ }^{13}$ Along with the medical certification requirement, an applicant must be of certain age (between 18 and 65) and be resident of particular province to be eligible for the benefits.
} 
This is an author-produced, peer-reviewed version of this article. The final, definitive version of this document can be found online at Journal of Population Economics, published by Springer. Copyright restrictions may apply. doi: 10.1007/s00148-015-0557-9

tightening eligibility requirements, and imposing work requirements on welfare recipients. As explained in more detail in the next section, we utilize the dramatic change in benefits over this period to estimate the effects of parental disability benefits on the gap in child well-being. ${ }^{14}$

Table 1 shows the maximum real annual disability benefits (2008 constant dollars) for a single individual under ten provincial programs for the NLSCY survey years, and measures of both cross-section and time-series variations in benefit schedules. The data are compiled from various volumes of Welfare Incomes by the National Council of Welfare. ${ }^{15}$ On average, Ontario, Alberta, British Columbia and Quebec offered the highest annual benefit level at $\$ 13,385, \$ 12,803$, \$11,096 and \$10,481 per person, respectively, whereas the benefits were lowest in New Brunswick, Manitoba and Nova Scotia, which paid \$8,685, \$9,540 and \$9,971 per person annually. In all provinces, the real value of disability benefits decreased (PEI, Nova Scotia, New Brunswick, Ontario, Manitoba and Saskatchewan) during the 14 year window or remained roughly constant (Quebec, British Columbia and Newfoundland. ${ }^{16}$

\section{("Insert Table 1 Here")}

\section{Empirical Strategy}

We use a continuous difference-in-differences (DD) estimator to control for potential unobserved heterogeneity associated with parental disability and benefit status. Assuming that the level of disability benefits is determined by provincial legislation and the level can only influence children's outcomes indirectly through individual families' circumstances, correlations between changes in benefit generosity and child outcome measures will imply that increasing parental disability income improves child development.

Because these assumptions will be violated if there are unmeasured province-specific transitory shocks that are correlated with both benefit generosity and children's outcomes, we use the children of non-disabled parents who live in the same province as comparison group and test whether the outcome gap - i.e. the difference in outcomes between children of disabled and non-disabled parents - is related to benefits changes over time.

Specifically, we estimate the following model for a cross-sectional sample, pooling data from 1994-2008 of the NLSCY:

$$
Y_{i p t}=\beta_{0}+\beta_{1} B E N_{p t}+\beta_{2} D I S_{i p t}+\delta B E N_{p t} \times D I S_{i p t}+X_{i p t} \theta+\varphi_{t}+\pi_{p}+\varepsilon_{i p t}
$$

where $\mathrm{i}$ is individual child, $\mathrm{p}$ is province and $\mathrm{t}$ is survey year. Y represents a child's outcome, DIS is a dummy variable indicating the disability status of a parent, and BEN is a continuous variable capturing the real maximum disability benefit level that prevailed in the previous year. In this regression, $\pi_{p}$ includes dummy variables for each of the ten

\footnotetext{
${ }^{14}$ We use the maximum benefit in the empirical analysis, because we do not know the disability payments that are actually received by individuals, and because these would be endogenous with child outcomes.

${ }^{15}$ The National Council of Welfare computes the disability benefits as the sum of the basic assistance rate (i.e. amounts for food, clothing, shelter and utilities, personal and household needs), additional benefits (i.e. supplementary allowances that were automatically provided to persons with a disability), and the provincial tax credit and GST credit that are intended for the disabled. These estimates assume a single disabled person who: (1) qualifies for long-term rates of assistance; (2) lives in the largest urban area in the province or territory; (3) goes on disability benefits on January 1 of each year and remains on benefits for the entire calendar year; and (4) is a tenant in the private rental market rather than a homeowner or social housing tenant, and who also does not share accommodation.

${ }^{16}$ In some provinces, actual entitlement to disability benefits may vary according to the circumstances of each individual family, including household size, composition and the children's age. We do not differentiate these family types because of data limitation, i.e. the National Council of Welfare did not produce benefit schedules for couplefamilies with a disability. Doing so also avoids potential endogeneity in fertility decisions and living arrangements to the generosity of needs-tested benefits (Moffitt 1990; Milligan 2005). We are unaware of any systematic legislation change that affected benefit schedules for single persons differently than for couple-families with a disability during the study period. This paper exploits within-province variations in benefit levels for the single disabled over time, which will reflect changes in benefit levels for other family types, unless there was such a change.
} 
This is an author-produced, peer-reviewed version of this article. The final, definitive version of this document can be found online at Journal of Population Economics, published by Springer. Copyright restrictions may apply. doi: 10.1007/s00148-015-0557-9

Canadian provinces (i.e. province fixed effects), while $\varphi_{t}$ includes dummy variables for years (i.e. year fixed effects). The province fixed effects hold constant unmeasured permanent differences across provinces, such as stable province differences in policies, such as regulations in earnings exemptions and asset limits, cost of living, the degree of discrimination against disabled people, and other disability-related services. The year fixed effects hold constant any time trends that affect all provinces similarly: changes in the federal disability tax credit in year 2004, for example. Since the disability benefit variable BEN is measured at the province-year level, we do not include any higher order interactions between province and year dummies in our preferred model specification. We do, however, experiment with an alternative that controls for the full set of province-year fixed effects and obtain highly similar results (more details see Section 6).

After centering, ${ }^{17} \beta_{1}$ picks up the average difference in outcomes across benefit levels that are common to both the children of disabled and non-disabled parents. $\beta_{2}$ indicates the average gap in outcome level between the children of disabled and non-disabled parents for those who are exposed to the average level of benefits. $\delta$ is the coefficient of interest. If higher disability benefits are associated with better child outcomes, we should expect to see a statistically significant $\delta$, indicating that the gap in outcomes between the children of disabled and non-disabled parents of the same province change when the benefit level varies.

In addition to province and year fixed effects, we include a set of covariates that may influence the well-being of children as suggested by existing literature: child age (in months) and age squared; gender; school grade; ${ }^{18}$ both parents' age (in years) and age squared, parents' immigration status (a dummy that equals one if either parent is an immigrant and zero otherwise), both parents' education in three categories (less than high school; high school graduate; and post-secondary diploma or some post-secondary education but not a degree), and interaction terms between both parents' education and disability status to allow for a differential impact of parental education between children with and without a disabled parent. Later, we also add a set of parental employment variables to examine the pathways through which parental disability transfers may benefit children. Importantly, since family income can be influenced by the size of the benefit, it is left out of our equation to avoid the introduction of a mechanical endogeneity.

It is possible that there is another provincial program that changes when the disability benefits program changes (e.g., because the province is cutting spending) and, though available to all children, is particularly relevant for children of disabled parents than for other children. If so, the effect of this program will be captured by the DIS x BEN variable and bias our estimates upward. To address this issue, we conduct two robustness checks.

First, we replicate the cross-sectional analysis with a sample that includes a more advantaged group: children of parents with a university degree. We compare benefit effect on outcome gaps between children of parents with and without disabilities and neither of the parents have a university degree, relative to the benefit effect on outcome gaps for children who have at least one parent with a university degree. Parents with a university degree may be more likely to hold skilled, stable jobs and less likely to file for welfare or be influenced by changes in means-tested benefits (but perhaps not by changes in other types of transfer programs). Finding smaller or non-existent effects among children of parents with a university degree would indicate that the impact of transitory provincial shocks is removed through our research design.

Second, we conduct a placebo analysis using an alternative type of expenditure that may be relevant for child wellbeing, provincial spending on public and private elementary and secondary education per school-age child. If the

\footnotetext{
${ }^{17}$ We subtract the sample mean from each respective benefit level.

${ }^{18}$ Since the difficulty of the math test in the NLSCY varies with the school grade of the child, the standardized scores increases as a child grows older (Lefebvre, Merrigan and Verstraete 2008). We thus include parent-report school grade ( $\mathrm{K}$ through ten) for the child in our regression. Inclusion of this variable causes less than $2 \%$ of four- to five-year olds who did not attend kindergarten to drop out of our estimation sample. In a robustness check that is not reported in this paper, inclusion of these children does not affect our results qualitatively (available upon request). In another study that uses the same data source (i.e. the NLSCY), we find only a very small number of children in grade K through four who do not comply with the school entry regulations in their year/province (Chen, Phipps and Fortin 2015). Our data is consistent with this finding.
} 
This is an author-produced, peer-reviewed version of this article. The final, definitive version of this document can be found online at Journal of Population Economics, published by Springer. Copyright restrictions may apply. doi: 10.1007/s00148-015-0557-9

estimated impact of disability benefit should, in fact, be attributed to changes in other public policies that are all potentially caused by the same provincial budget cut, a significant association between this policy variable and child outcomes should be expected.

In addition, the benefit claim, benefit duration and the incidence of self-reported disability may be positively influenced by the generosity of disability benefits (Fortin, Lacroix and Drolet 2004). If so, it may be that higher disability benefits change the composition of the disabled population rather than actually affecting child outcomes. As well, if parents with disabilities move to provinces that offer relatively more generous benefits, the resulting benefit effects will be mis-specified. To explore these possibilities, we first take advantage of the longitudinal structure of the NLSCY and conduct a panel DD analysis. While parental disability information in the NLSCY is not available for 1996 and 1998, we can pool three two-period panels that track three cohorts of children over six calendar years. These children aged 6-9 when first observed in 1994, 2000 and 2002 and 12-15 when last observed in 2000, 2006 and 2008 (more details are provided in Section 5). Based on this longitudinal sample, we estimate a child fixed effect model:

$$
\Delta Y_{i p t}=\beta_{0}+\beta_{1} \Delta B E N_{p t}+\delta \Delta B E N_{p t} \times D I S_{i p}+\Delta X_{i p t} \theta+\Delta \varphi_{t}+\Delta \varepsilon_{i p t}
$$

Here $\Delta$ represents the first difference of any variable between two adjacent time periods. Compared to the level specification for the cross-sectional sample (equation (1)), this model relies on more rigorous identifying assumptions. Any permanent unobserved parental characteristics associated with parental disability, and consequently the achievement gaps between children of disabled and non-disabled parents are removed in this first-difference setting. ${ }^{19}$ The panel DD estimator thus identifies the impact of disability benefit amount by considering only changes in child outcomes over time.

When estimating the panel models, we exclude children whose parents reported a change in disability status during the observation period to rule out the possibility of our results being driven by sample composition or reporting bias. In other words, our longitudinal sample is restricted to children whose parents reported a disability in both periods (i.e. "always disabled") and children whose parents never reported a disability (i.e. "always non-disabled") so that the same group of children are compared when benefits are high than low. We subsequently compare the results based on samples where children are allowed to move, where all moves are "reset" assuming that they lived in their original provinces, and where movers are excluded to assess the extent to which potential migration response to disability benefit levels may have influenced our estimated benefit effect.

We also investigate the heterogeneity of our results by considering the gender of the disabled parent. ${ }^{20}$ Evidence from a preliminary analysis on the underlying mechanisms is also presented. A more detailed discussion on the rationales and the methodology used is provided in Section 6 below.

Finally, we emphasize that this study uses an intention-to-treat design -- we do not actually know whether a particular disabled parent filed for or received disability benefits. Rather we examine whether a change in benefit generosity has an impact on the population most likely to be affected (i.e., disabled parents with low education). The analytic sample may include ineligible disabled parents as part of the treated group and also eligible parents who do not actually receive disability benefits. The average treatment effect on the treated (ATT) thus depends on the proportion of eligible

\footnotetext{
${ }^{19}$ For example, less patient parents may be more likely to engage in risky behavior, experience disability, and at the same time invest less time and money in children.

${ }^{20}$ The sample of children living in lone mothers where the lone mother had a disability was unfortunately too small to produce reliable estimates. To the extent that such families may be most affected by higher disability benefits, we may be underestimating effect size.
} 
This is an author-produced, peer-reviewed version of this article. The final, definitive version of this document can be found online at Journal of Population Economics, published by Springer. Copyright restrictions may apply. doi: 10.1007/s00148-015-0557-9

parents included in the sample, and the proportion of eligible parents who actually take up the benefits. ${ }^{21}$ All reported analyses use sampling weights, and the standard errors are clustered at the province level to account for a potential serial correlation on observations of children in the same province over time. ${ }^{22}$

\section{Data, Sample, and Measures}

Empirical analysis is based on the 1994-2008 National Longitudinal Survey of Children and Youth (NLSCY), combined with province-level data capturing variations in disability benefit levels. The NSLCY is an on-going survey of Canadian children and youth, designed to help analyze child development and well-being. Starting in 1994, it has followed a nationally representative sample of children aged between 0 and 11 years at two-year intervals until they reach the age of 25. At each survey round, a new cohort of children aged 0-1 was added to the longitudinal files allowing for the construction of a sizable cross-sectional sample. A unique feature of the NLSCY is that it provides inter-generational information on parents' activity limitation, and a variety of children's developmental outcomes along with detailed socio-economic characteristics of both parents. For every selected child under 17 years of age, a question is asked to identify who in the household is most knowledgeable about the child (PMK). The PMK then provides the information for each selected child and for him/herself and him/her spouse/partner. In over $98 \%$ of cases, the PMK is the mother of the child.

For our main estimation sample, we use data from 1994, 2000, 2002, 2004, 2006 and 2008 of the NLSCY, and restrict attention to non-disabled children aged between 4 and 15 years old who lived in two-parent families. These are the years when most children should be attending kindergarten through grade ten. Data from 1996 and 1998 and for children aged 16 years or above are omitted because the set of questions on parental disabilities was not available. We also exclude younger children from our analysis to avoid the complex task of differentiating the program effects from the effects of schooling. In addition, certain disabling conditions can be transmitted genetically. In order to focus on the effect of disability benefits and minimize the risk of its effect being confounded with that of the child's own health problems, we exclude children with disabilities. Finally, divorce / re-marriage can involve non-income-related stress for both children and their parents, which would be difficult to separate from benefit changes at the same time. To obtain the cleanest estimates possible, we focus on children of intact families. ${ }^{23}$ Children of single parents are later included into our analysis to obtain a more representative estimate for all children who may be affected by the benefit generosity.

Because the purpose of this study was to examine the effects of the program on child well-being, we include only a subset of families that are most likely to be eligible for the disability benefits. Specifically, we select children in families where both parents are between 18 and 65 years, since provincial welfare programs required beneficiaries to be of 18-65 age. In addition, since needs-tested disability benefits target low-income families and tend to have the largest impact on people with lower education, we select children in families where neither parent has a university degree.

\footnotetext{
${ }^{21}$ Data on the take-up rate of means-tested disability benefits in Canada are unfortunately difficult to obtain. Based on our only source of information, Prince (2008), using the 2001 Participation and Activity Limitation Survey (PALS) reports that, of the 3.42 million of Canadian adults with disabilities, $10 \%$ received income support from provincial disability benefit programs. If the vast majority of benefit recipients do not have a university degree, the benefit takeup rate can be around $15 \%$ among the population under analysis, since about $70 \%$ of children reported to live with parents neither of whom has a university degree during our study period. If true, the ATT effect of disability benefits should be 6-7 times as large as the size of the ITT effect estimated in current paper. However, since the unit of analysis in the NLSCY is the child instead of the adult, above extrapolation is rather crude and cautions should be taken in interpretation.

${ }^{22}$ Given our main coefficient of interest is the benefit effect on children, we choose to cluster standard errors at the highest level with the smallest number of clusters, which is a relatively conservative strategy. Clustering at the household level produces qualitatively similar results.

${ }^{23}$ Children living in lone-parent families make up only $3 \%$ of all children aged between 4 and 15 years in the NLSCY. To the extent that lower benefits may increase the chance of parental separation / divorce and/or such families may be most affected by changes in benefit levels, we may be underestimating effect size.
} 
This is an author-produced, peer-reviewed version of this article. The final, definitive version of this document can be found online at Journal of Population Economics, published by Springer. Copyright restrictions may apply. doi: 10.1007/s00148-015-0557-9

We consider three domains of children's developmental outcomes: cognitive, behavioural and emotional well-being. Cognitive outcomes are measured by children's standardized math test score. The math test (CAT/2 test) in the NLSCY is designed to measure a child's basic competencies in math (e.g. addition, subtraction, multiplication and division of integers) and is administered to children in grade 2 to 10 every year. It is a shorter version of the Mathematics Computation Test taken from the Canadian Achievement Test, 2nd edition, with scores ranging from 0 to 750. The hyperactivity score is derived from six statements by the PMK about the child having trouble sitting still or being restless, being easily distracted, being inattentive, having trouble sticking to any activity, concentrating, paying attention for long, being impulsive, acting without thinking, having difficulty waiting for his turn in games or groups. The emotional anxiety score is derived from six statements about the child being unhappy or sad, not as happy as other children, fearful or nervous, worried, crying a lot, being high strung or tense, having trouble enjoying himself or herself. Parents respond to these two scores on a scale ranging from 0 to 14, with 14 indicating the highest level of hyperactivity or emotional anxiety. ${ }^{24}$

We define parental disability to be a functional restriction in activities performed at home, at school, at work, in other activities such as transportation to or from work or leisure time activities, or in caring for children. ${ }^{25}$ Note that these are not mutually exclusive categories -- more than $80 \%$ of parents in our main estimation sample indicated limitations in multiple functional domains. For this reason and also to obtain the largest sample size possible, we do not distinguish children of parents who suffer from disabilities in different functional domains, though the impact of disability on parenting, and hence the extent to which income transfers may alter child outcomes can vary with the nature of the disability. ${ }^{26}$

Based on this definition, $20 \%$ of children under analysis lived with at least one disabled parent (the bottom row of Table 2). This group consists of all children aged 4 to 15 years in two-parent families where neither parents has a university degree and where the child himself/herself did not have a disability. Out of this total, $10 \%$ lived with a disabled mother, $9.8 \%$ lived with a disabled father, and $2.7 \%$ lived with two disabled parents. Summary statistics of family characteristics for these children are provided in Table 2. Several features are noticeable. First, parents with disabilities were slightly older than parents without disabilities (mean ages of mothers and fathers are 38.8 vs. 38.1 and 41.8 vs. 40.2), as are their non-disabled spouses (mean ages of mothers and fathers are 38.8 vs. 38.1 and 41.2 vs. 40.2). Second, relative to parents without disabilities, parents with disabilities have lower education (16.8 \% and 22.7 $\%$ dropped out of high school as compared to $15.2 \%$ and $19.5 \%$ of able-bodied mothers and fathers), ${ }^{27}$ and are less likely to be employed (probabilities of working for mothers and fathers are $70 \%$ vs. $80 \%$ and $88 \%$ vs. $97 \%$ ). Even if they have a job, they tend to work less hours during a week (mean weekly hours for mothers and fathers are 23.4 vs. 27.4 and 38.2 vs. 43.2) and are less likely to be employed full-time (probabilities of working more than 30 hours per week for mothers and fathers are $47.8 \%$ vs. $56.5 \%$ and $83 \%$ vs. $94.5 \%$ ). Third, the socioeconomic characteristics of their non-disabled spouses tend to be more similar to those of parents in families without a disabled parent. $29 \%$ of non-disabled fathers in mother-disabled families and $32.4 \%$ of non-disabled mothers in father-disabled families had some post-secondary education (but not a university degree), compared to $27.3 \%$ and $26.9 \%$ of their non-disabled counterparts. In addition, both non-disabled mothers in father-disabled families and non-disabled fathers in motherdisabled families work more than parents in families without disabilities, especially on the intensive margin: $57.4 \%$

\footnotetext{
${ }^{24}$ Earlier cycles contained an additional question for each scale. We re-constructed these scales by dropping this question so they can be compared consistently across cycles.

${ }^{25}$ The survey question that we used to identify parental disability in the NLSCY is as follows: "Because of a longterm physical or mental condition or a health problem, are/is ... ... ... limited in the kind or amount of activity you/he/she can do: 1) At home? 2) At school? 3) At work? 4) In other activities such as transportation to or from work or leisure time activities? 5) In caring for children?". If the parent answered "yes" to any of the above items for herself or her spouse, parental disability is coded one indicating disabled, otherwise zero for non-disabled.

${ }^{26}$ In assessing the impact of parental disability on parenting, we conduct a simple descriptive analysis on the association between disabilities of different functional domains and child outcomes (see Appendix Table 3). In general, all types except for limitations at transportation/leisure/other are associated with significantly worse outcomes of children even after adjusting for child gender, age and school grade. There is, however, no clear pattern suggesting one matters more than another, possibly due to the high correlation among the limitations reported in different functional domains.

${ }^{27}$ A chi-squared test for group difference suggests a statistically significant difference for the latter.
} 
This is an author-produced, peer-reviewed version of this article. The final, definitive version of this document can be found online at Journal of Population Economics, published by Springer. Copyright restrictions may apply. doi: 10.1007/s00148-015-0557-9

of non-disabled mothers in father-disabled families and $95.2 \%$ of non-disabled fathers in mother-disabled families worked more than 30 hours per week, whereas the corresponding figures for their non-disabled counterparts are 56.5 $\%$ and $94.5 \%$, respectively.

\section{('Insert Table 2 Here')}

Relative to families of non-disabled parents, the equivalent family income for families with a disabled parent was approximately 5 \% lower. ${ }^{28}$ Taking Statistics Canada's Low-Income-Cut-Off (LICO) as an unofficial poverty line shows that having a disabled parent in the household almost doubled the incidence of poverty among these children: $13.5 \%$ of children with disabled parents lived below the LICO while the corresponding number for children with nondisabled parents was only $9.1 \%$. There is also considerable heterogeneity depending on the gender of the disabled parent: families in which the mother is disabled are much less likely to be in low-income situations than families with a disabled father. The former thus seems to have significantly lowered the risk of poverty status by having a highearning male spouse in the family.

Despite differences in income, children of disabled parents consistently do worse than their peers with non-disabled parents (upper panel of Table 3). Cross-tabulation of children's outcomes suggests that children of disabled parents on average score $8 \%$ of one standard deviation lower on standardized math tests and living with a disabled parent is associated with a $13 \%$ and $16 \%$ of one standard deviations more hyperactive symptoms and anxiety behavior. Compared to children of fathers with a disability, children of mothers with a disability appear to fare worse (columns 3 and 4 of Table 3). Results based on a larger sample that includes children of parents with a university degree reveal more or less the same story (lower panel of Table 3).

\section{('Insert Table 3 Here')}

To get a sense of whether family income is more important for families with a disabled parent, we estimate, for descriptive purposes, two child outcome equations: 1) for children of disabled, and; 2) for children of non-disabled parents (Table 4). Conditional on the set of child and parent characteristics discussed above, family equivalent income does not appear to have a stronger association with the hyperactivity or anxiety of children with a disabled parent, but is strongly associated with math score. ${ }^{29}$ However, acquiring the same level of income may involve very different amounts of time (e.g. in one- versus two-earners families), and parental time is another key determinant of child outcomes. In the analysis to follow, we thus use a more sophisticated approach to examine this hypothesis.

\section{('Insert Table 4 Here')}

Aside from the NLSCY, information on provincial regulations, such as disability benefit levels, is compiled from various issues of Welfare Incomes (1993-2007), Social Assistance Statistics Report (2004-2007), and each provincial program's website. Since most family income and parents' labour market activities in the NLSCY are reported retrospectively over a 12-month period, we use the disability benefit schedule that prevailed in January of the previous calendar year. The program data is then merged to the NLSCY data based on the province of residence reported by individual households. All benefits and income data are converted into 2008 dollars using the corresponding provincial seasonally adjusted Consumer Price Index. ${ }^{30}$

\footnotetext{
${ }^{28}$ In this study, we use the Luxembourg Income Study (LIS) scale to calculate "equivalent income." The LIS scale is calculated as the square root of family size.

${ }^{29}$ For the sake of completeness, we also report coefficients on other covariates in the model. These results indicate that: (1) conditional on school grade, older children score higher on standardized math test, but tend to exhibit more hyperactive symptoms and anxiety behavior; (2) boys do better at math tests but suffer more hyperactive symptoms than girls; (3) compared with children of high school dropouts, children of parents with a high school degree or postsecondary education have better outcomes in all three cases.

${ }^{30}$ Consumer Price Index (CPI), 2011 basket content is from Statistics Canada's CANSIM (database) Table 326-0021: http://www5.statcan.gc.ca/cansim/home-accueil?lang=eng. Access on April 4, 2013.
} 
This is an author-produced, peer-reviewed version of this article. The final, definitive version of this document can be found online at Journal of Population Economics, published by Springer. Copyright restrictions may apply. doi: 10.1007/s00148-015-0557-9

\section{Empirical Results}

\subsection{Effects of Parental Disability Benefits on Children's Well-being}

Table 5 presents DD estimates of equation (1) above for the pooled cross-sectional sample. As earlier noted, the key variable of interest in the regressions on children's outcomes is the interacted variable [Benefits*Disability]. For each outcome, Table 5 reports results from three model specifications. Column (1) adjusts only for year fixed effects, child's age in month, gender and school grade. Estimates from this most basic model reveal a positive association between the generosity of disability benefits and children's math test scores, and negative associations between the benefits, hyperactive symptoms and emotional anxiety, where a higher value indicates worse outcomes. In column (2), indicators that control for province fixed effects are added to the regressions. If provinces that provide higher benefits tend to be generous in other public spending programs, and if these programs have especially favourable impacts on children with disabled parents, adding in these controls would reduce the estimated benefit effects - but column (2) lends little support to this hypothesis. There is a moderate drop in the estimated benefit effect on math scores, and the magnitude of the estimates for hyperactivity and anxiety increases slightly, which suggests that the unmeasured heterogeneity across provinces is unlikely to explain the observed link between the child's outcome gap and parental disability benefits. In columns (3) and (4), the inclusion of socio-economic characteristics of both parents and the set of province-year fixed effects again does not change the results substantially. ${ }^{31}$ As one would expect, the fit of the regressions (adjusted $R^{2}$ ) increases significantly as the province fixed effects and parental background are controlled for. For reasons stated in Section 4, we treat model (3) as our preferred model specification.

\section{('Insert Table 5 Here')}

The results from column (3) imply that a $\$ 1,000$ reduction in real disability benefits ${ }^{32}$ results in a $1 \%$ of a standard deviation (1.02 point) decrease in math scores, $3.7 \%$ of a standard deviation (0.11 point) and $2.8 \%$ of a standard deviation ( 0.06 point) increase in hyperactive symptoms and emotional anxiety. Hence, a cut in real benefits by $\$ 3,000$, the equivalent of cuts enacted in Ontario between 1994-2000 (i.e. around $10 \%$ of the equivalent family income for families with a disabled parent in the sample) will reduce standardized math test scores for children with disabled parents by $3 \%$ of a standard deviation, and increase hyperactive symptoms and anxiety by 11 and $8 \%$ of a standard deviation, respectively. To put these estimates in context, in the same specification mothers having a high school degree (compared to dropping out) is respectively associated with 12, 14 and $10 \%$ of a standard deviation improvement in math test score, hyperactive and anxiety symptoms (results not reported but available upon request). In other words, the effect of a $\$ 3,000$ benefit reduction is one third as large as the magnitude of the association between maternal high school education and math score, and nearly as large as the association between maternal high school education and child hyperactivity and anxiety. Relative to gains in cognitive functioning, the effects of disability benefits on the child's behavioural and emotional well-being seem more substantial. ${ }^{33}$

The parental disability variable indicates that children with disabled parents on average score lower in standardized math tests and exhibit more hyperactive and anxiety problems than their peers with non-disabled parents. ${ }^{34}$ The coefficient on benefit levels, suggests that all children in a province tend to do worse in years when disability benefits are higher. Since real disability benefits decreased in most provinces during our study period, this result may partially reflect the within-province time trend in child outcomes, which encompasses the effects of various concurrent province expenditures on child outcomes.

\footnotetext{
${ }^{31}$ A fully interacted model that includes interaction between parental disability dummy and every single covariate in the regression produces highly similar results (available upon request).

${ }^{32}$ In our regression analysis, the disability benefit variable is measured in 1,000 dollars.

${ }^{33}$ Cognitive achievement is more likely to be linked to the cumulative process of human capital acquisition (Todd and Wolpin 2007) as opposed to external shocks, such as variations in family income, or parental stress associated with employment.

${ }^{34}$ We do not attach any fundamental meaning to these estimates since in the presence of interaction terms, their magnitude and significance merely reflect the group difference at the average benefit level and whether or not this difference is statistically different from zero at this point.
} 
This is an author-produced, peer-reviewed version of this article. The final, definitive version of this document can be found online at Journal of Population Economics, published by Springer. Copyright restrictions may apply. doi: 10.1007/s00148-015-0557-9

\subsection{Correlated Policies}

To test the robustness of our main results, we first present two variants of the DD cross-sectional estimates in Table 5. Table 6 shows results that are estimated based on the sample of children either of whose parents has a university degree. The model specification is identical to that in column (3) of Table 5. For ease of comparison, we reproduce the results from our original model in column (1). As shown before, for children in families where neither parent has a university degree, there is a positive and statistically significant association between changes in children's outcome gaps and changes in disability benefits. The results presented in column (2) for children in families where at least one parent has a university degree, however, are strikingly different. Despite the qualitatively similar estimates for the main effects of parental disability and disability benefit levels, the coefficients on their interaction terms are small in magnitude and insignificant at any conventional level for all outcomes. In the case of emotional anxiety, the sign of the estimated effects is even reversed. This sharp contrast suggests that most of the associations between disability benefits and children's developmental outcomes are driven by children whose parents have lower education, who are the target population of means-tested disability benefits.

\section{('Insert Table 6 Here')}

Table 7 presents results from a placebo analysis using another type of expenditure that is relevant for child well-being, provincial spending on public and private elementary and secondary education. In the construction of this variable, we normalize the raw data by the total number of school-age children in a given province-year, and convert it into 2008 constant dollars using corresponding provincial Consumer Price Index. We refer to it as "education spending per capita". ${ }^{35}$ To be consistent with our previous analysis of disability benefits, we use the expenditure amount in the calendar year preceding the survey date. The results of this estimation are provided in columns (2) and (3) of Table 7. Column (2) augments our original model with education spending per capita as a further control. The inclusion of this alternative measure has negligible impact on our estimated benefit effects. Column (3) re-estimates our model replacing the level of disability benefits with that of education spending per capita. In all three cases, the estimated effect of provincial education expenditure on children of disabled parents is small and insignificant. The magnitude is between $2 \%$ and $30 \%$ as large as those we obtain for disability benefits. Finding that changes in provincial expenditures on education are unrelated to the developmental outcome gap of children with disabled parents provides some evidence that our results are unlikely to be attributed to concurrent changes in other public policies (e.g., because the provincial budget is tight).

('Insert Table 7 Here')

\subsection{Sample Composition, Endogenous Treatment Status and Migration}

Besides correlated policies, there are several other ways, in which our identifying assumption can be violated, from sample composition change, from selection into disability status, or from inter-provincial migration in response to different disability benefit levels. In this section, we explore these possibilities with alternative techniques and data samples.

Table 8 presents panel DD estimates of equation (2) for our longitudinal sample that includes three cohorts of children aged between 6/9 (at the first observation) and 12/15 (at the second observation). To ensure the same group of children is compared when the benefits are high versus low, we keep children in families where there was no change in parental disability status. This effectively removes all children in families where a parent experienced the "onset" of a disability or "recovered" from a negative health event. Due to data constraints, we are only able to examine children's performance on standardized math tests for this analysis. ${ }^{36}$

\footnotetext{
${ }^{35}$ Data on the provincial expenditure of education (Table 478-0014) and Consumer Price Index (Table 326-0021) were retrieved on April 4, 2013 from Statistics Canada's CANSIM (database): //www5.statcan.gc.ca/cansim/homeaccueil?lang=eng. We extrapolate the total number of school-age children by province by year using data from cycles 1-8 of the NLSCY.

${ }^{36}$ As part of Early Child Development (ECD) initiative, the NLSCY dropped many young children aged 6-10 from its cross-sectional sample in later cycles. Standardized math test score thus is the only outcome for which there is sufficient sample in each year to enable comparisons over time.
} 
This is an author-produced, peer-reviewed version of this article. The final, definitive version of this document can be found online at Journal of Population Economics, published by Springer. Copyright restrictions may apply. doi: 10.1007/s00148-015-0557-9

('Insert Table 8 Here')

The first three columns of Table 8 show, respectively, the results from child-fixed effects based on the full sample, a sample that "resets" all movers to their original provinces, and a sub-sample that excludes all inter-provincial movers. ${ }^{37}$ These results indicate even stronger benefit effects on children of disabled parents. Overall, a $\$ 1,000$ decrease in disability benefit leads to $7 \%$ of one standard deviation reduction in math test scores. Taking into account possible migration response to disability benefit levels by assuming all children remain in their original provinces also enhances the estimated effect of disability benefits. Excluding all movers from the estimation sample results in a slightly smaller but still statistically significant estimated effect. This confirms that migration responses do not drive our main findings.

Relative to the cross-sectional DD estimates, the effect size of disability benefits from our panel estimation is substantially larger, which may reflect a combination of three factors. First, given that we exclude switchers, and only consider individuals who were disabled all years in the panel DD estimates, it is possible that these individuals are on average more likely to actually get the benefit with respect to the individuals in the cross-sectional sample, and the ITT is for this reason closer to being an ATT in this sample. Second, the use of child fixed effects eliminates the downward bias in our cross-sectional estimates that is attributable to unobserved heterogeneity associated with parental disability. Parents with disabilities may be disadvantaged relative to parents without disabilities in both the labor market and home activities in ways that are unobservable to us. Without adequately controlling for these differences or without a randomization strategy, worse developmental outcomes of the child can be attributed to parental disability without necessarily a causal interpretation. Third, children of parents with a long-term disability are the least well-off, thus improvement in parental incomes is likely to generate larger beneficial effects than for children of parents only temporarily disabled.

As discussed in Section 3, PEI changed its basic earnings exemption level during our observation period (from $\$ 600$ to $\$ 900$ per month in 2001). The disability benefit program in Alberta (i.e. the Assured Income for the Severely Handicapped (AISH)) also has rules that are somewhat different from those in the rest of Canada. The last six columns of Table 8 report results after excluding children residing in these two provinces. The benefit effect estimates are very similar to the ones reported earlier. Any potential bias in the estimated results stemming from differences in other parameters of the program should thus be small.

Finally, we determine treatment (intent-to-treat) status using parents' self-reported activity limitation status. An advantage of this approach relative to using actual disability benefit receipt is that it seems less likely to be affected by economic incentives. Yet there is still a possibility that respondents mis-report disability status as a justification for other behaviors, such as less intensive work hours or benefit claims when the disability benefit level is high. For instance, Haveman and Wolfe (2000) suggest that the self-reported presence of a work limitation may increase for workers in redundant industries or for older workers during periods of high unemployment.

Results from our panel DD estimation provide indirect proof that this behavior pattern is not extensive in our context. We now take a more direct approach to examine this hypothesis by estimating a linear probability model of the probability of parental disability as a function of the benefit level, while controlling for the same set of controls as in our original model (see Table 9). Consistent with existing literature, these results indicate that self-reported disability is more prevalent for non-immigrant parents, as well as parents with less than high school education. Conditional on the set of child- and parent-characteristics, however, there is no relationship between benefit levels and the reported incidence of parental disability.

\section{('Insert Table 9')}

Given a disabling condition, an individual may be granted benefit status in one province but not the other, depending on the stringency of the screening process. Ideally, we would like to conduct an empirical analysis on the association between changes in benefit size with the take-up rates within provinces over time, but data are difficult to obtain. ${ }^{38}$

\footnotetext{
${ }^{37}$ Less than $2 \%$ of children in the estimation samples moved inter-provincially during our study period.

${ }^{38}$ Apart from published statistics, we cannot find any existing studies that estimate, or extrapolate the rate of take-up for a means-tested disability benefit program in Canada.
} 
This is an author-produced, peer-reviewed version of this article. The final, definitive version of this document can be found online at Journal of Population Economics, published by Springer. Copyright restrictions may apply. doi: 10.1007/s00148-015-0557-9

Instead, we collect information on the numbers of cases and recipients for a representative province, Ontario (i.e. Ontario Disability Support Program), and compare this to the level of the benefit prevailing at the same time (see Appendix Table 2). Overall, it seems that the administrators tend to get more "lenient" when the benefit level is lower. All else being equal, if, on average applicants who were admitted into the programs were of better health over time (given that benefit levels declined over time), this would imply a potential under-estimation of the true benefit effect in our context. ${ }^{39}$ Therefore, even with a likely downward bias, our estimates suggest a beneficial impact of parental disability benefits on the well-being of children.

\title{
6.4. Maternal versus Paternal Disability Benefit Effects
}

Does it matter whether it is the mother or father who is disabled? On the one hand, traditional gender roles assign home production and care for children primarily to mothers, so their disability especially impedes the delivery of time inputs. On the other hand, because male wages tend to be higher, disability will likely have a larger impact on household living standards when the father is disabled - so the father's disability may especially affect material inputs in home production. There may also be a gendered disincentive effect of disability benefits across disabled fathers and mothers. Given a certain level of benefit, mothers with a disabled spouse may be less likely to increase their labour supply relative to fathers with a disabled spouse because of a "nursing effect" (e.g. Berger and Fleisher 1984; Berger 1983). If lower benefits push poor parents, especially the non-disabled fathers to work long hours and thus reduce time spent with the child, a reduction in disability benefit level may be more detrimental to children with a disabled mother than children with a disabled father. The bottom two panels of Table 10 investigate this issue by separately estimating model (3) in Table 5 for children in families with only the mother or only the father being disabled. For ease of interpretation, we omit children with both parents disabled. ${ }^{40}$ For children of mothers with a disability, the benefit effect estimates are significant across outcomes and, even though the treated cases are reduced by half, their magnitudes are even larger than the ones reported in column (3) of Table 5, suggesting that the favourable impact of benefit changes discovered before is mainly concentrated on children in families where the mother is disabled. Ceteris paribus, a $\$ 1,000$ benefit reduction results in a $2 \%$ of one standard deviation reduction in math test scores, and a 6 and $5 \%$ of one standard deviation increase in parent-report hyperactive and anxiety symptoms. In direct contrast, the benefit effect estimates for children of fathers with a disability are all insignificant with considerably smaller magnitudes.

\author{
('Insert Table 10')
}

\subsection{Exploring Mechanisms}

As noted before, means-tested disability benefits can create incentives for parents to modify their behaviors. A benefit reduction thus may hurt children by lowering family income (material inputs in home production) or by increasing parental employment (thereby reducing time spent participating in activities with children). To gain further insights into the underlying mechanisms through which parental disability benefits may affect child well-being, we examine whether there is evidence that parental employment and family income are affected by lowered benefits. Given the existing evidence on a potential asymmetric "added worker effect" across disabled husbands and wives (e.g. Coile 2004), we estimate separate models of labor supply for disabled fathers and mothers. ${ }^{41}$

\footnotetext{
${ }^{39}$ In addition, most existing research in Canadian context seems to agree that the rise and fall of the number of people on welfare do not coincide with benefit levels. As pointed out by a survey by the National Council of Welfare (1998), every significant study has shown that welfare caseload growth tends to coincide with periods of recession and rise of unemployment. It is not the meager benefit levels that attract people to welfare or discourage them from leaving to find a job.

${ }^{40}$ Around 200 children, representing $10 \%$ of all children with at least one disabled parents are excluded from our estimation samples.

${ }^{41}$ The NLSCY contains retrospective information on labour market activities for both parents such as paid work participation, usual weekly hours, and family income received from all sources (before taxes), 12 months prior to the survey. Parents reported their hours of work in six categories: less than 10 hours, 10-19 hours, 20-29 hours, 30-39 hours, 40-49 hours and 50 hours or more. We create a pseudo continuous variable coded at the mid-point of each category to capture the non-linear nature of parental hours, and another indicator variable that identifies a parent's full-time work status (i.e. equal to one if a parent works 30 hours or more), to test the effect of hours of work.
} 
This is an author-produced, peer-reviewed version of this article. The final, definitive version of this document can be found online at Journal of Population Economics, published by Springer. Copyright restrictions may apply. doi: 10.1007/s00148-015-0557-9

Table 11 presents DD estimates for models of parental weekly hours of work, full-time employment, defined as exceeding 30 hours per week (columns (1)-(4)), and family income (columns (5)). ${ }^{42}$ The upper, middle and lower panel show, respectively, results for children in the estimation samples of math score, hyperactivity and anxiety, respectively. Columns (1)-(2) show a large and negative labor supply effect of disability benefits for the disabled parents. For every $\$ 1,000$ decrease in annual benefits, disabled mothers and fathers increase their time spent in the labor market by 0.70 and 0.67 hours per week, respectively. The change in paid hours in both cases is mainly driven by an increase in the extent of full-time employment. Living in a province with a benefit reduction of $\$ 1,000$ increases the probability of engaging in a full-time job for both disabled mothers and fathers by around 0.02 percentage points. ${ }^{43}$ Columns (3)-(4) show an asymmetric added worker effect for the non-disabled spouses. A \$1,000 decline in the disability benefits leads the non-disabled father to increase his time spent in the labour market by 0.3-0.5 hours per week ( $1 \%$ of the average hours of work), and increases his probability of participating in full-time employment by around 1 percentage point. In contrast, the effects on non-disabled mothers are much smaller and statistically insignificant. ${ }^{44}$

\section{('Insert Table 11 Here')}

The benefit effect on family income is negative in both cases (column (5)). Consistent with the missing added worker effect, lower benefits results in a greater increase in income for families with a disabled mother (every $\$ 1,000$ benefit reduction associated with $2.5 \%$ increase in real equivalent family income versus $1.9 \%$ for families where the father is disabled ${ }^{45}$ ), in which poorer child outcomes are observed.

Taken together, these results suggest that the link between lower benefits and increased time away from home of the non-disabled father may be what causes poorer child outcomes. To further test the plausibility of this hypothesis, we re-estimate our original models for children of disabled mothers, adding both mother and father's labor market variables (Table 12). If the benefit effect operates through this channel, we would expect the estimated benefit effect coefficient to decline under this specification. Results in column (2) of Table 12 suggest that, after additionally controlling for parental employment, the estimated association between disability benefits and child's math test scores diminishes, though those in child hyperactivity and emotional anxiety equations are not substantially affected. The statistical significance of the benefit effect coefficient completely disappears, and its quantitative magnitude drops moderately. The interaction between the non-disabled father's full-time employment and maternal disability is significant on its own, indicating that having the non-disabled father working long hours negatively affects children in families with a disabled mother more than those with an able-bodied mother.

\section{('Insert Table 12 Here')}

Of course, parents' employment status and working hours can be endogenous to child outcomes. If fathers who are able to work longer hours differ from those who do not in ways that benefit children (e.g. better health), the unobserved heterogeneity may generate an upward bias for the estimated effects. As well, they can be related to the degree of disability, for which we are unfortunately not able to control in this study due to the lack of data. We thus interpret this result as preliminary evidence. However, the finding of a stronger association between the non-disabled father's

\footnotetext{
${ }^{42}$ As mentioned before, a reduction in disability benefits will both directly decrease poor families' disposable incomes and induce poor parents to participate more in paid work. Although a negative association between benefit level and parental paid work for both the disabled parent and his or her non-disabled spouse is to be expected, the benefit effect on family income is ambiguous.

${ }^{43}$ Considering that in our sample mothers' average weekly hours is lower than fathers', the size of benefit effect for own-labour supply is slightly larger for disabled mothers than disabled fathers.

${ }^{44}$ Overall, there seems to be an asymmetric incentive effects on spousal labour supply - as the benefit level declines, fathers of disabled spouse increase their full-time employment and hours of work. By contrast, wives of disabled spouse do not behave differently. The pattern is consistent with previous research on the effect of spousal ill-health on labour supply in particular, husband's health on wife's labour supply in North America (Berger and Fleisher 1984; Berger 1983; Gallipoli and Turner 2009), and studies related to spill-over effects of public transfer payments in the U.S. (e.g. Colie 2004). However, cautions should be taken in interpretation since the unit of analysis in the NLSCY is the child instead of the adult. Even though the results can be replicated when one parent per child is randomly selected (results available upon request), further analysis using alternative data sources is needed.

${ }^{45} \mathrm{Log}$ of family income measure is used in column (5).
} 
This is an author-produced, peer-reviewed version of this article. The final, definitive version of this document can be found online at Journal of Population Economics, published by Springer. Copyright restrictions may apply. doi: 10.1007/s00148-015-0557-9

time and child's cognition than behavioural outcomes is in line with Curtis and Phipps (2006), who find available parental time to be a correlate of school success but not general health for children in the NLSCY. Presumably, time is a particularly important input both for direct help with homework, enriching outings and reading to children, for example, and for indirect support of school activities (e.g. home and school work, volunteering at the school, going along on school outings). As well, a father's long work hours could also impose stress on a family from which parents cannot successfully shield the child. It is unfortunately not feasible to estimate a model of parental stress or depression in this scenario, as Milligan and Stabile (2011) did, because depression could well be a cause or result of the mother's disability, or, could even be the mother's disability.

Alternatively, the "good mother hypothesis" might explain why the developmental returns of parental disability benefits may be larger for children with disabled mothers than children with disabled fathers. If a mother's income is more likely than a father's income to be spent in ways that benefit the child, given a disabling condition, benefits received by the mother may increase her independent access to family financial resources, enhance her bargaining power in household expenditure decision-making process and thus have a larger positive effect on child well-being. When Lundberg, Pollak and Wales (1997) studied the effect of a change in family allowance benefits which decreases father's net income in the United Kingdom in the late 1970s, they found that expenditures on children's clothing increased significantly relative to expenditures on men's clothing as a result of this policy change. Woolley (2004) uses data from Canada and finds that the monthly child tax benefits paid to mothers relieves women's financial dependence and are more likely to be spent on children.

\section{Conclusions}

This paper has asked: 1) Do higher disability benefits reduce the gap in child outcomes between the children of disabled and non-disabled parents? 2) If so, are the benefit effects different depending on the gender of the disabled parent? 3) Finally, what are the mechanisms that drive these differences? Using changes in real benefits under ten disability benefit programs in Canada as an identification strategy and data from the NLSCY as our data source, we find higher parental disability benefits indirectly protect child development and cognitive skill formation for children in families with low education. Specifically, the gaps in developmental outcomes between children of disabled parents and children of non-disabled parents grow wider in provinces that decrease their benefits compared to provinces that do not. In addition, the benefits have stronger effects on children's behaviour problems and emotional anxiety, than on children's cognitive ability as measured by standardized math test scores. We interpret these estimates as causal effects of parental disability benefits, because a family's exposure to benefits affects the parents' income and employment, while it is independent of unmeasured characteristics.

Although parental disability is self-identified by parents through a checklist of questions, there is little evidence suggesting that the results are driven by reporting bias, screening stringency, sample composition change or unobserved family-level heterogeneity associated with parental disability. The additional robustness checks for correlated polices and inter-provincial migration response, including a "placebo" type of DD estimator for the less likely eligible (i.e. university educated) sample lend additional support to the main finding.

We also find that there is a difference in the benefit effect depending on the gender of the disabled parent: lower benefits have strong detrimental effects for children with a disabled mother, while the effects are small and insignificant for children with a disabled father. For families with a disabled mother, benefit reductions significantly increase the non-disabled father's full-time employment. Holding the father's employment status constant, estimated benefit effect drops moderately, suggesting that lower benefits may hurt children partially through the time constraints and stress associated with the non-disabled father's longer employment. This finding is line with related Canadian studies that emphasize both parental time and money as important inputs to the well-being of children (Lethbridge and Phipps 2006; Burton, Lethbridge and Phipps 2008). A tight family budget directly limits the material resources that parents can afford for children (Mayer and Jencks 1993; Brooks-Gunn and Duncan 1997), but parents' long hours of work can reduce the amount of time parents can spend with children, erode parental health, and increase stress levels, all of which negatively affect the well-being of children. A second explanation for the results is the "good mother hypothesis" that a mother's income is more likely than a father's income to be spent in ways that benefit children.

Since the mid-1990s, Canadian policy makers have made significant changes to welfare programs, in the general direction of connecting cash transfers to labour market participation. This paper's findings suggest that reduced 
This is an author-produced, peer-reviewed version of this article. The final, definitive version of this document can be found online at Journal of Population Economics, published by Springer. Copyright restrictions may apply. doi: 10.1007/s00148-015-0557-9

income support to parents with disabilities may have had unintended adverse consequences for the well-being of their children. Governments in Canada continue to pay disability benefits that are now distinctly lower, in real terms, than twenty years ago. However, it is important not to lose sight of the fact that the children who live in poor households with disabled parents already face a gap in equality of opportunity due to their parent's disability - and that outcome gap widens when disability benefits are cut. 


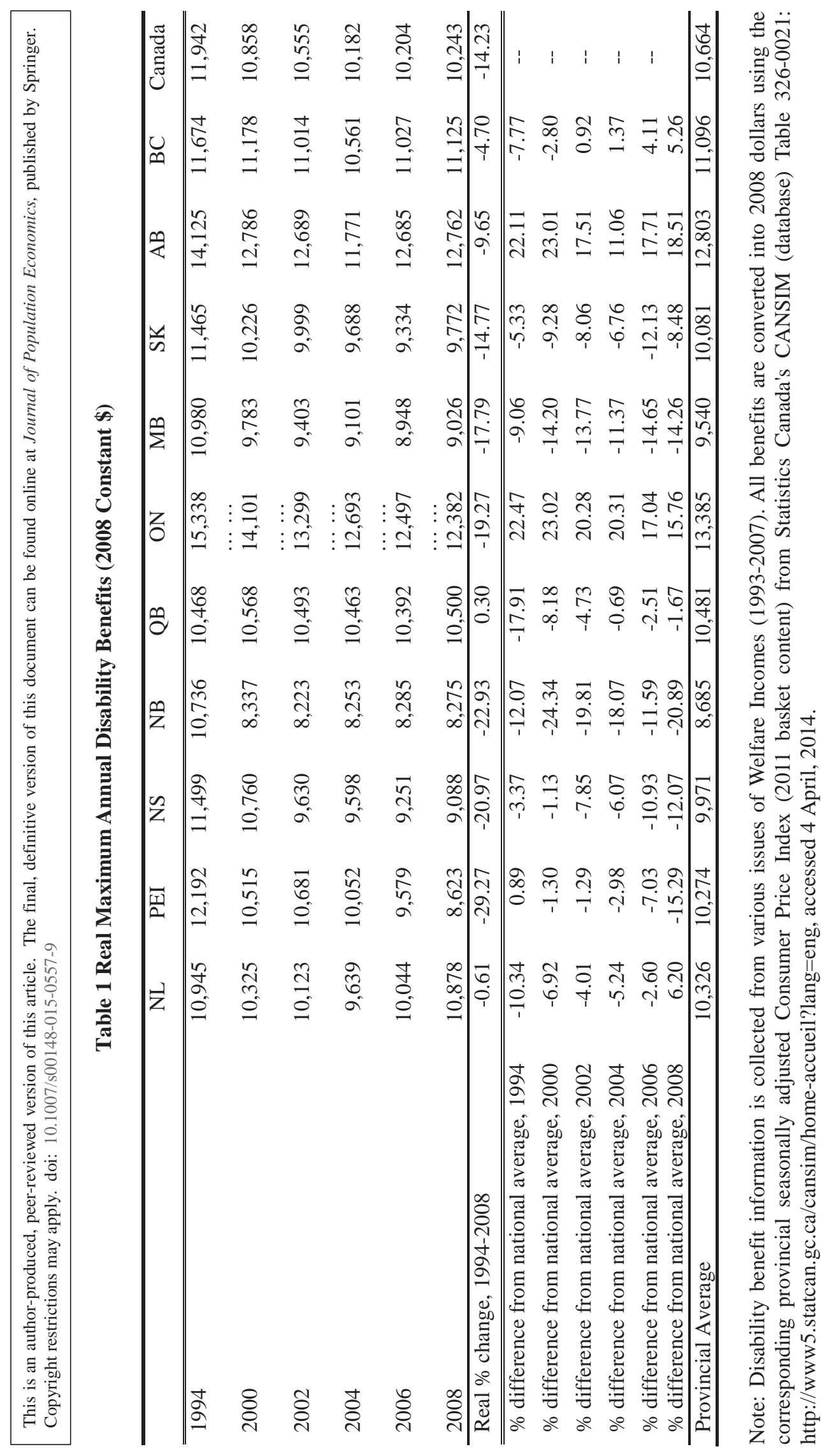


This is an author-produced, peer-reviewed version of this article. The final, definitive version of this document can be found online at Journal of Population Economics, published by Springer. Copyright restrictions may apply. doi: 10.1007/s00148-015-0557-9

Table 2 Means for Independent Variables by Parental Disability Status. Neither Parent Has a University Degree.

\begin{tabular}{|c|c|c|c|c|}
\hline & $\begin{array}{l}\text { No Parent } \\
\text { Disabled } \\
\text { (1) } \\
\end{array}$ & $\begin{array}{c}\text { At Least One } \\
\text { Parent Disabled } \\
(2)\end{array}$ & $\begin{array}{l}\text { Only Mother } \\
\text { Disabled } \\
\text { (3) }\end{array}$ & $\begin{array}{c}\text { Only Father } \\
\text { Disabled } \\
(4) \\
\end{array}$ \\
\hline & \multicolumn{4}{|c|}{ Child-level Characteristics } \\
\hline Child Age in Months & 126 & 131 & 134 & 129 \\
\hline Child Female \% & 49.3 & 50.5 & 51.3 & 50.3 \\
\hline School Grade & 4.9 & 5.3 & 5.5 & 5.1 \\
\hline & \multicolumn{4}{|c|}{ Family-level Characteristics } \\
\hline $\begin{array}{l}\text { Equivalent Family Income } \\
\text { (2008 Constant Dollar) }\end{array}$ & $\$ 38,259$ & $\$ 36,431$ & $\$ 38,255$ & $\$ 35,679$ \\
\hline Below LICO \% & 9.1 & 13.5 & 9.9 & 13.5 \\
\hline Either Parent Immigrant \% & 18.8 & 18.9 & 17.5 & 19.9 \\
\hline Mother Age in Years & 38.1 & 38.8 & 38.8 & 38.8 \\
\hline $\begin{array}{l}\text { Education of Mother Post- } \\
\text { Secondary Diploma \% }\end{array}$ & 29 & 30.2 & 29 & 32.8 \\
\hline $\begin{array}{l}\text { Education of Mother High } \\
\text { School Degree \% }\end{array}$ & 55.8 & 53.1 & 54.2 & 50.9 \\
\hline $\begin{array}{l}\text { Education of Mother High } \\
\text { School Dropout \% }\end{array}$ & 15.2 & 16.7 & 16.8 & 16.3 \\
\hline Mother Employment Status \% & 80.2 & 73.4 & 70.5 & 79.8 \\
\hline Mother Weekly Hours & 27.4 & 24.6 & 23.4 & 27.6 \\
\hline Mother Weekly Hours 30 + \% & 56.5 & 50.1 & 47.8 & 57.4 \\
\hline Father Age in Years & 40.2 & 41.6 & 41.2 & 41.8 \\
\hline $\begin{array}{l}\text { Education of Father Post- } \\
\text { Secondary Diploma \% }\end{array}$ & 28.5 & 28.5 & 28 & 28.6 \\
\hline $\begin{array}{l}\text { Education of Father High } \\
\text { School Degree \% }\end{array}$ & 52 & 50.5 & 51.2 & 48.7 \\
\hline $\begin{array}{c}\text { Education of Father High } \\
\text { School Dropout \% }\end{array}$ & 19.5 & 21 & 20.8 & 22.7 \\
\hline Father Employment Status \% & 96.7 & 90.5 & 96.6 & 87.5 \\
\hline Father Weekly Hours & 43.2 & 37.84 & 43.6 & 38.2 \\
\hline Father Weekly Hours $30+\%$ & 94.5 & 87.3 & 95.2 & 83 \\
\hline Number of Observations & 17,143 & 3,742 & 1,744 & 1,617 \\
\hline
\end{tabular}

Note: The sample consists of non-disabled children aged between 4 and 15 in two-parent families whose parents were 18 and 65 years of age and did not have any university degree. Children with two disabled parents (371 children) are excluded from the only-mother-disabled and only-father-disabled families. Descriptive statistics for this group of children are suppressed to avoid disclosure risks. Since the developmental stage for which an outcome measure was collected differs, children in this sample may have missing data on one or two of the dependent variables. Our analysis is conducted based on the largest sample possible for each outcome, so the sample size varies across models. 
This is an author-produced, peer-reviewed version of this article. The final, definitive version of this document can be found online at Journal of Population Economics, published by Springer. Copyright restrictions may apply. doi: 10.1007/s00148-015-0557-9

Table 3 Children's Developmental Outcomes and Family Income by Parental Disability

\begin{tabular}{|c|c|c|c|c|}
\hline & $\begin{array}{l}\text { No Parent } \\
\text { Disabled } \\
\text { (1) }\end{array}$ & $\begin{array}{l}\text { At Least One Parent } \\
\text { Disabled } \\
\text { (2) }\end{array}$ & $\begin{array}{l}\text { Only Mother } \\
\text { Disabled } \\
\text { (3) }\end{array}$ & $\begin{array}{l}\text { Only Father } \\
\text { Disabled } \\
\text { (4) }\end{array}$ \\
\hline \multicolumn{5}{|c|}{ Non-Disabled Children (Neither Parent has a University Degree) } \\
\hline Standardized Math & 476 & $466 * *$ & $467 * *$ & 473 \\
\hline \multirow[t]{2}{*}{ Score } & $(108)$ & $(104)$ & $(106)$ & $(105)$ \\
\hline & {$[11,454]$} & {$[2,835]$} & {$[1,276]$} & {$[1,244]$} \\
\hline \multirow[t]{3}{*}{ Hyperactive Symptoms } & 3.76 & $4.14^{* * *}$ & $4.20^{* * *}$ & $4.11^{* * *}$ \\
\hline & $(2.98)$ & (3.12) & $(3.21)$ & (3.03) \\
\hline & {$[11,846]$} & {$[2,496]$} & {$[1,112]$} & {$[1,116]$} \\
\hline \multirow[t]{3}{*}{ Emotional Anxiety } & 2.17 & $2.54 * * *$ & $2.65^{* * *}$ & $2.46^{* * *}$ \\
\hline & $(2.15)$ & $(2.23)$ & $(2.34)$ & $(2.16)$ \\
\hline & {$[11,860]$} & {$[2,491]$} & {$[1,110]$} & {$[1,116]$} \\
\hline \multicolumn{5}{|c|}{ Non-Disabled Children (Full Sample) } \\
\hline \multirow{3}{*}{$\begin{array}{l}\text { Standardized Math } \\
\text { Score }\end{array}$} & 484 & $475^{* *}$ & $474 * *$ & 480 \\
\hline & $(114)$ & $(109)$ & $(109)$ & $(112)$ \\
\hline & {$[17,112]$} & {$[3,854]$} & {$[1,724]$} & {$[1,717]$} \\
\hline \multirow[t]{3}{*}{ Hyperactive Symptoms } & 3.60 & $3.99 * * *$ & $3.98^{* * *}$ & $3.95^{* * *}$ \\
\hline & (2.91) & $(2.91)$ & (3.15) & (3.04) \\
\hline & {$[17,111]$} & {$[3,274]$} & {$[1,485]$} & {$[1,461]$} \\
\hline \multirow[t]{3}{*}{ Emotional Anxiety } & 2.15 & $2.50 * * *$ & $2.55^{* * *}$ & $2.45 * * *$ \\
\hline & $(2.13)$ & $(2.23)$ & $(2.26)$ & $(2.23)$ \\
\hline & {$[17,127]$} & {$[3,269]$} & {$[1,483]$} & {$[1,461]$} \\
\hline
\end{tabular}

Note: The standardized math test scores are collected for children in grades two through ten. The hyperactive symptom and emotional anxiety are available for children aged four through eleven years old. The upper panel of the table is based on sub-samples drawn from the 20,885 children reported in Table 2 restricting to those with non-missing data on the outcome of interest. The lower panel of the table additionally includes children whose one or both parents has a university degree with all else held constant. Children both of whose parents are disabled are excluded from the only-mother-disabled and only-father-disabled families. Descriptive statistics for this group of children are suppressed in order to avoid possible residual disclosure. Number of observations and standard deviation are in square bracket and parentheses, respectively. The number of stars denotes the p-value of a t-test for group difference. ${ }^{*} \mathrm{p}<0.1$; ${ }^{* *} \mathrm{p}<0.05 ; * * * \mathrm{p}<0.01$. 
This is an author-produced, peer-reviewed version of this article. The final, definitive version of this document can be found online at Journal of Population Economics, published by Springer. Copyright restrictions may apply. doi: 10.1007/s00148-015-0557-9

Table 4 OLS Regressions of Child Outcomes on Family Income for Families with and without a Parent with a Disability

\begin{tabular}{|c|c|c|c|c|c|c|}
\hline & \multicolumn{2}{|c|}{ Standardized Math Score } & \multicolumn{2}{|c|}{$\begin{array}{c}\text { Hyperactivity } \\
\text { Symptoms }\end{array}$} & \multicolumn{2}{|c|}{ Emotional Anxiety } \\
\hline & $\begin{array}{c}\text { Non- } \\
\text { Disabled } \\
\text { (1) }\end{array}$ & $\begin{array}{c}\text { Disabled } \\
\text { (2) }\end{array}$ & $\begin{array}{c}\text { Non- } \\
\text { Disabled } \\
(1)\end{array}$ & $\begin{array}{c}\text { Disabled } \\
\text { (2) }\end{array}$ & $\begin{array}{c}\text { Non- } \\
\text { Disabled } \\
\text { (1) }\end{array}$ & $\begin{array}{c}\text { Disabled } \\
\text { (2) }\end{array}$ \\
\hline Equivalent Family Income & 2.301 & $13.554^{* * *}$ & 0.014 & 0.295 & -0.058 & -0.070 \\
\hline (2008 Constant Dollar) (log of) & $(2.753)$ & $(4.351)$ & $(0.096)$ & $(0.181)$ & $(0.076)$ & $(0.130)$ \\
\hline Child Age in Months & $\begin{array}{l}1.720^{\text {**** }} \\
(0.416)\end{array}$ & $\begin{array}{l}1.817^{* * *} \\
(0.641)\end{array}$ & $\begin{array}{l}0.028^{* *} \\
(0.013)\end{array}$ & $\begin{array}{c}0.040 \\
(0.029)\end{array}$ & $\begin{array}{c}0.046^{* * *} \\
(0.010)\end{array}$ & $\begin{array}{c}0.030 \\
(0.020)\end{array}$ \\
\hline Child Age Squared & $\begin{array}{c}-0.0006 \\
(0.001)\end{array}$ & $\begin{array}{r}-0.0002 \\
(0.002)\end{array}$ & $\begin{array}{l}-0.0001^{* *} \\
(0.00007)\end{array}$ & $\begin{array}{c}-0.0003^{* *} \\
(0.0001)\end{array}$ & $\begin{array}{l}-0.0001^{* * * *} \\
(0.00005)\end{array}$ & $\begin{array}{c}-0.00008 \\
(0.0001)\end{array}$ \\
\hline School Grade & $\begin{array}{c}19.129^{* * *} \\
(3.830)\end{array}$ & $\begin{array}{c}15.831^{* * * *} \\
(3.607)\end{array}$ & $\begin{array}{l}-0.056 \\
(0.101)\end{array}$ & $\begin{array}{l}-0.039 \\
(0.151)\end{array}$ & $\begin{array}{l}-0.106 \\
(0.068)\end{array}$ & $\begin{array}{l}-0.145 \\
(0.105)\end{array}$ \\
\hline Child Female & $\begin{array}{l}-2.030 \\
(2.539)\end{array}$ & $\begin{array}{l}-7.184^{*} \\
(3.732)\end{array}$ & $\begin{array}{l}-1.042^{* * *} \\
(0.0931)\end{array}$ & $\begin{array}{c}-1.168^{* * *} \\
(0.181)\end{array}$ & $\begin{array}{c}0.070 \\
(0.067)\end{array}$ & $\begin{array}{c}0.142 \\
(0.140)\end{array}$ \\
\hline Either Parent Immigrant & $\begin{array}{c}4.451 \\
(4.241)\end{array}$ & $\begin{array}{c}2.856 \\
(6.332)\end{array}$ & $\begin{array}{l}-0.129 \\
(0.145)\end{array}$ & $\begin{array}{l}-0.556^{*} \\
(0.320)\end{array}$ & $\begin{array}{l}0.0815 \\
(0.116)\end{array}$ & $\begin{array}{l}-0.290 \\
(0.181)\end{array}$ \\
\hline Mother Diploma & $\begin{array}{c}19.016^{* * * *} \\
(4.001)\end{array}$ & $\begin{array}{l}12.293^{*} \\
(6.548)\end{array}$ & $\begin{array}{c}-0.366^{* *} \\
(0.170)\end{array}$ & $\begin{array}{l}-0.027 \\
(0.296)\end{array}$ & $\begin{array}{c}-0.034 \\
(0.134)\end{array}$ & $\begin{array}{c}0.133 \\
(0.204)\end{array}$ \\
\hline Father Diploma & $\begin{array}{l}7.935^{* *} \\
(3.893)\end{array}$ & $\begin{array}{c}5.917 \\
(5.858)\end{array}$ & $\begin{array}{l}-0.059 \\
(0.138)\end{array}$ & $\begin{array}{l}-0.036 \\
(0.304)\end{array}$ & $\begin{array}{c}0.0690 \\
(0.113)\end{array}$ & $\begin{array}{l}0.387^{* *} \\
(0.195)\end{array}$ \\
\hline Mother High School & $\begin{array}{c}12.768^{* * *} \\
(3.659)\end{array}$ & $\begin{array}{c}11.926^{* *} \\
(5.883)\end{array}$ & $\begin{array}{c}-0.393^{* * *} \\
(0.146)\end{array}$ & $\begin{array}{c}0.192 \\
(0.284)\end{array}$ & $\begin{array}{l}-0.206^{*} \\
(0.118)\end{array}$ & $\begin{array}{c}0.262 \\
(0.183)\end{array}$ \\
\hline Father High School & $\begin{array}{c}4.752 \\
(3.226)\end{array}$ & $\begin{array}{c}7.393 \\
(5.157)\end{array}$ & $\begin{array}{l}-0.125 \\
(0.120)\end{array}$ & $\begin{array}{c}-0.133 \\
(0.273)\end{array}$ & $\begin{array}{c}0.0119 \\
(0.102)\end{array}$ & $\begin{array}{c}0.269 \\
(0.173)\end{array}$ \\
\hline Mother Age in Years & $\begin{array}{c}2.521 \\
(3.157)\end{array}$ & $\begin{array}{c}-0.5148 \\
(3.800)\end{array}$ & $\begin{array}{c}-0.054 \\
(0.116)\end{array}$ & $\begin{array}{c}-0.191 \\
(0.170)\end{array}$ & $\begin{array}{c}-0.081 \\
(0.072)\end{array}$ & $\begin{array}{c}-0.225^{* *} \\
(0.111)\end{array}$ \\
\hline Mother Age Squared & $\begin{array}{c}-0.0229 \\
(0.040)\end{array}$ & $\begin{array}{c}0.025 \\
(0.048)\end{array}$ & $\begin{array}{c}0.0004 \\
(0.001)\end{array}$ & $\begin{array}{c}0.002 \\
(0.002)\end{array}$ & $\begin{array}{c}0.0007 \\
(0.0009)\end{array}$ & $\begin{array}{c}0.003^{*} \\
(0.001)\end{array}$ \\
\hline Father Age in Years & $\begin{array}{l}-0.166 \\
(2.454)\end{array}$ & $\begin{array}{l}-0.187 \\
(3.005)\end{array}$ & $\begin{array}{c}-0.099 \\
(0.091)\end{array}$ & $\begin{array}{c}0.004 \\
(0.139)\end{array}$ & $\begin{array}{c}0.007 \\
(0.061)\end{array}$ & $\begin{array}{c}0.107 \\
(0.080)\end{array}$ \\
\hline Father Age Squared & $\begin{array}{c}0.006 \\
(0.029)\end{array}$ & $\begin{array}{l}-0.002 \\
(0.033)\end{array}$ & $\begin{array}{c}0.001 \\
(0.001)\end{array}$ & $\begin{array}{c}-0.00002 \\
(0.002)\end{array}$ & $\begin{array}{l}-0.0003 \\
(0.0007)\end{array}$ & $\begin{array}{c}-0.001 \\
(0.0009)\end{array}$ \\
\hline $\mathrm{N}$ & 11,454 & 2,835 & 11,846 & 2,496 & 11,860 & 2,491 \\
\hline Adjusted $R^{2}$ & 0.650 & 0.650 & 0.059 & 0.096 & 0.034 & 0.033 \\
\hline
\end{tabular}

Notes: This table reports results from separate child outcome equations for children of non-disabled (column (1)) and disabled (column (2)) parents in our estimation sample, including family income for descriptive purposes. Province and year fixed effects are included but not reported. Robust standard errors (in parentheses) are clustered at the household level. ${ }^{*} p<0.1,{ }^{* *} p<0.05,{ }^{* * *} p<0.01$. 


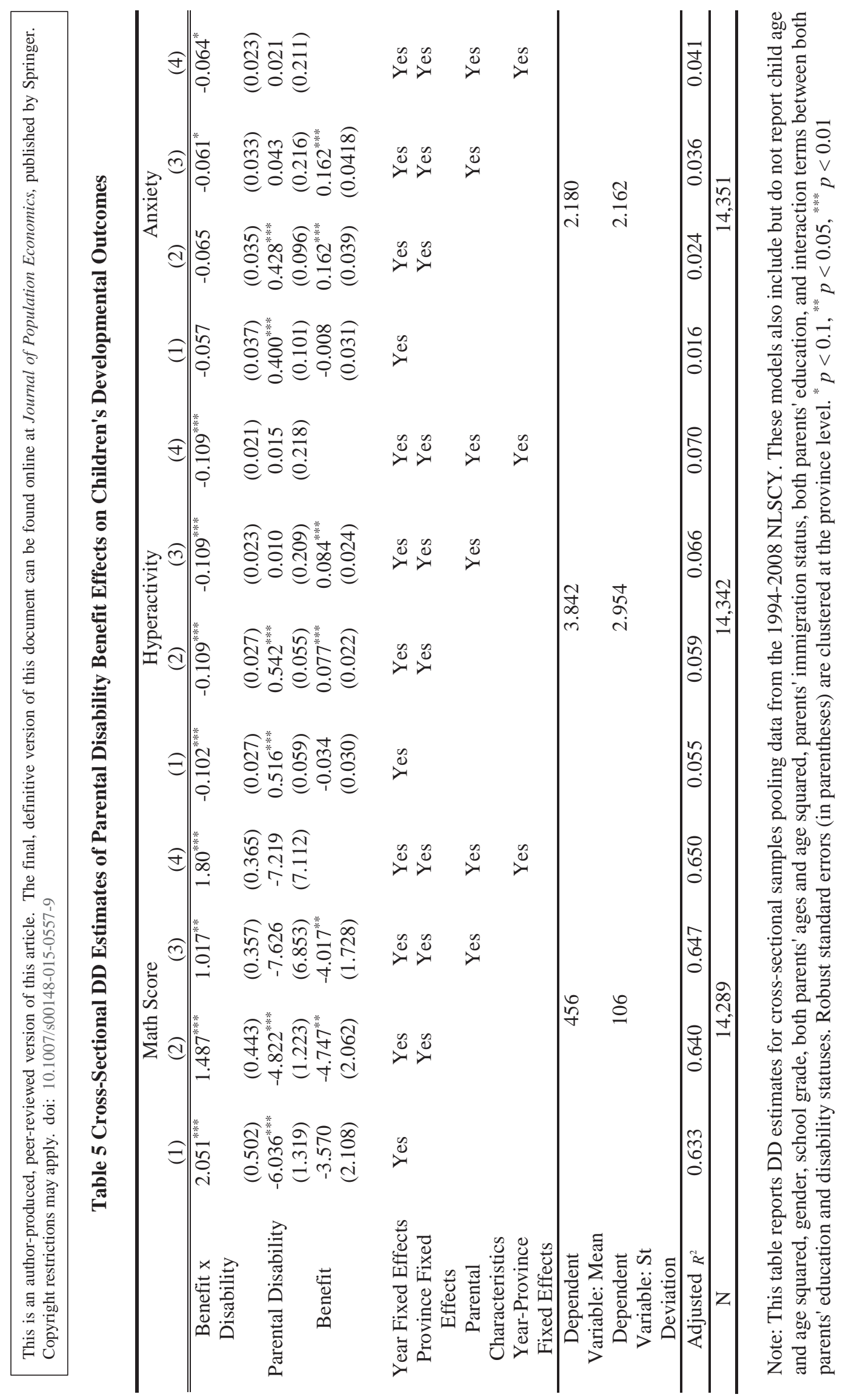




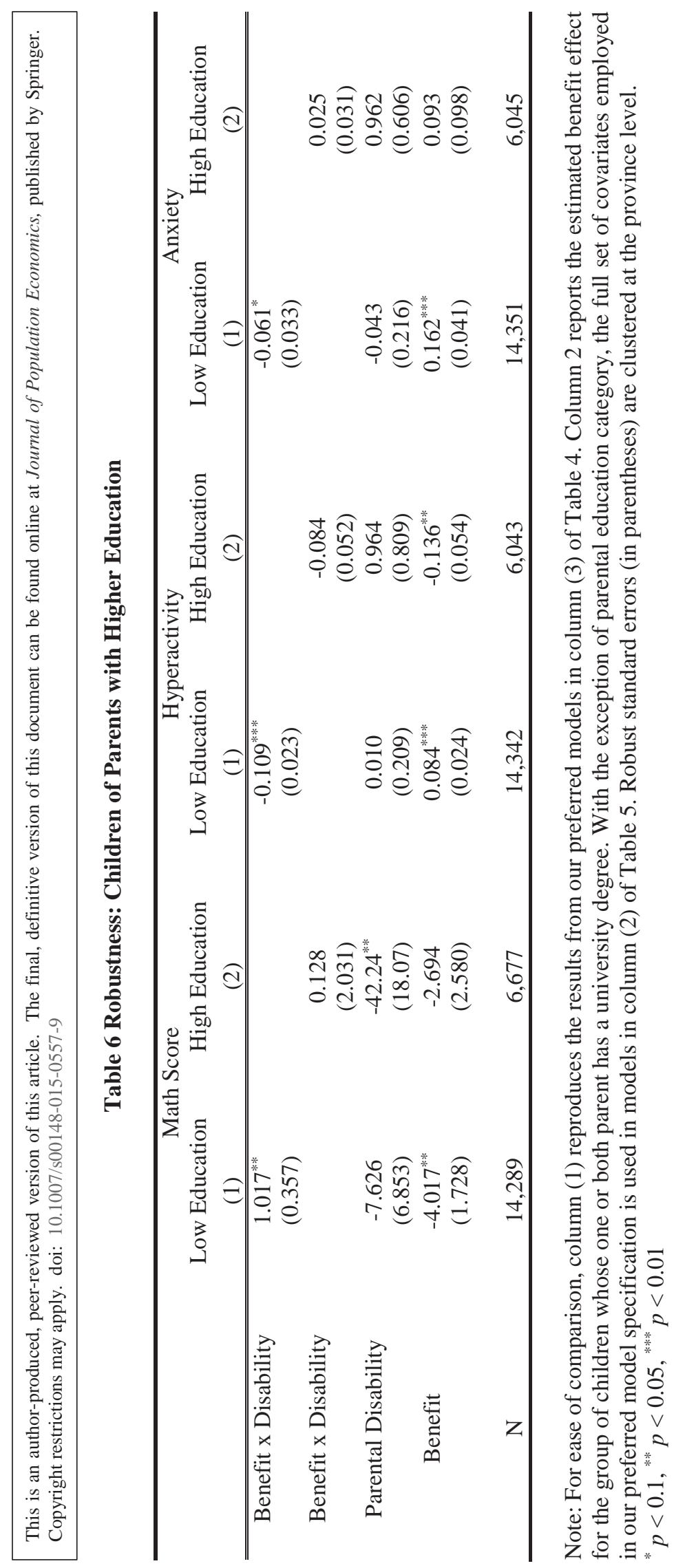




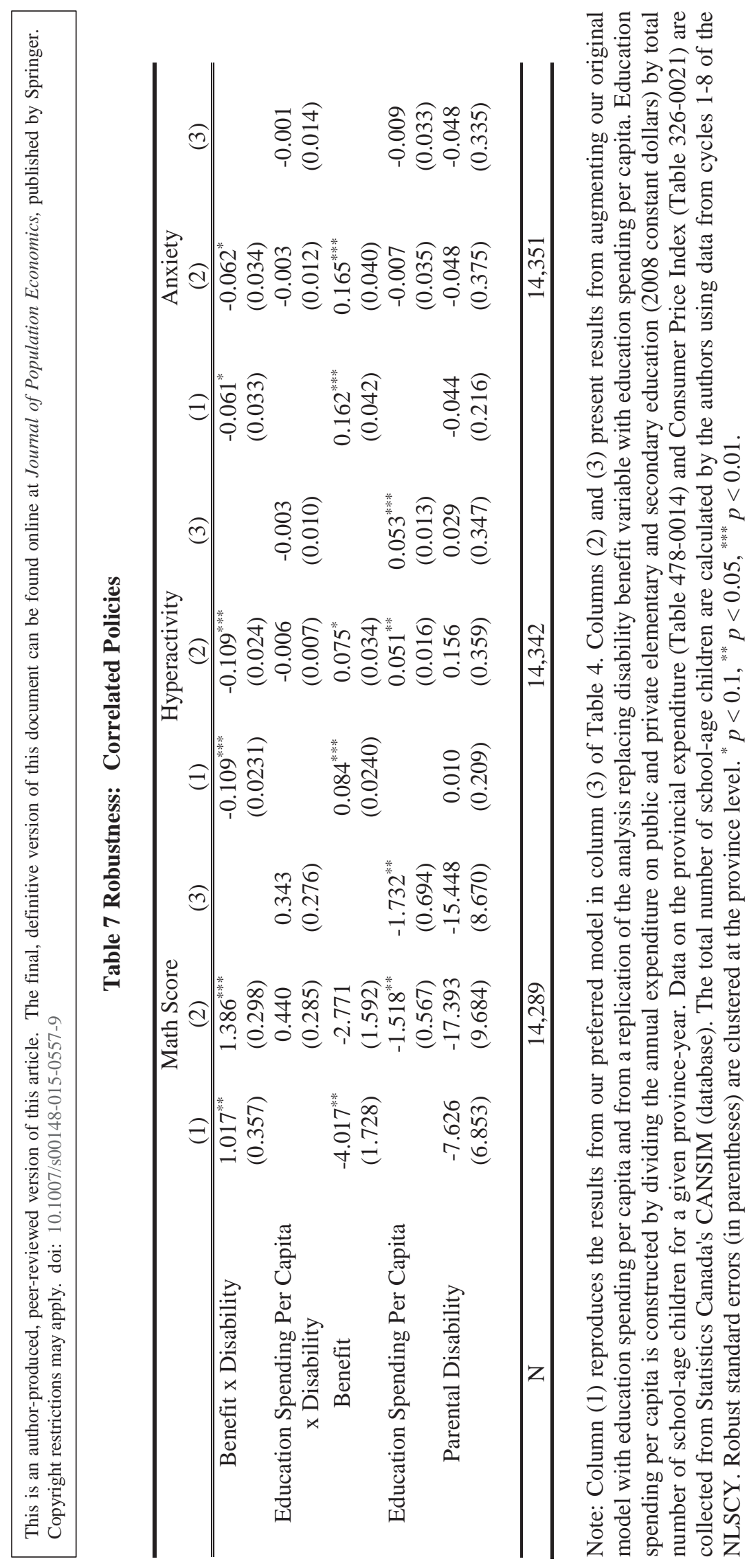




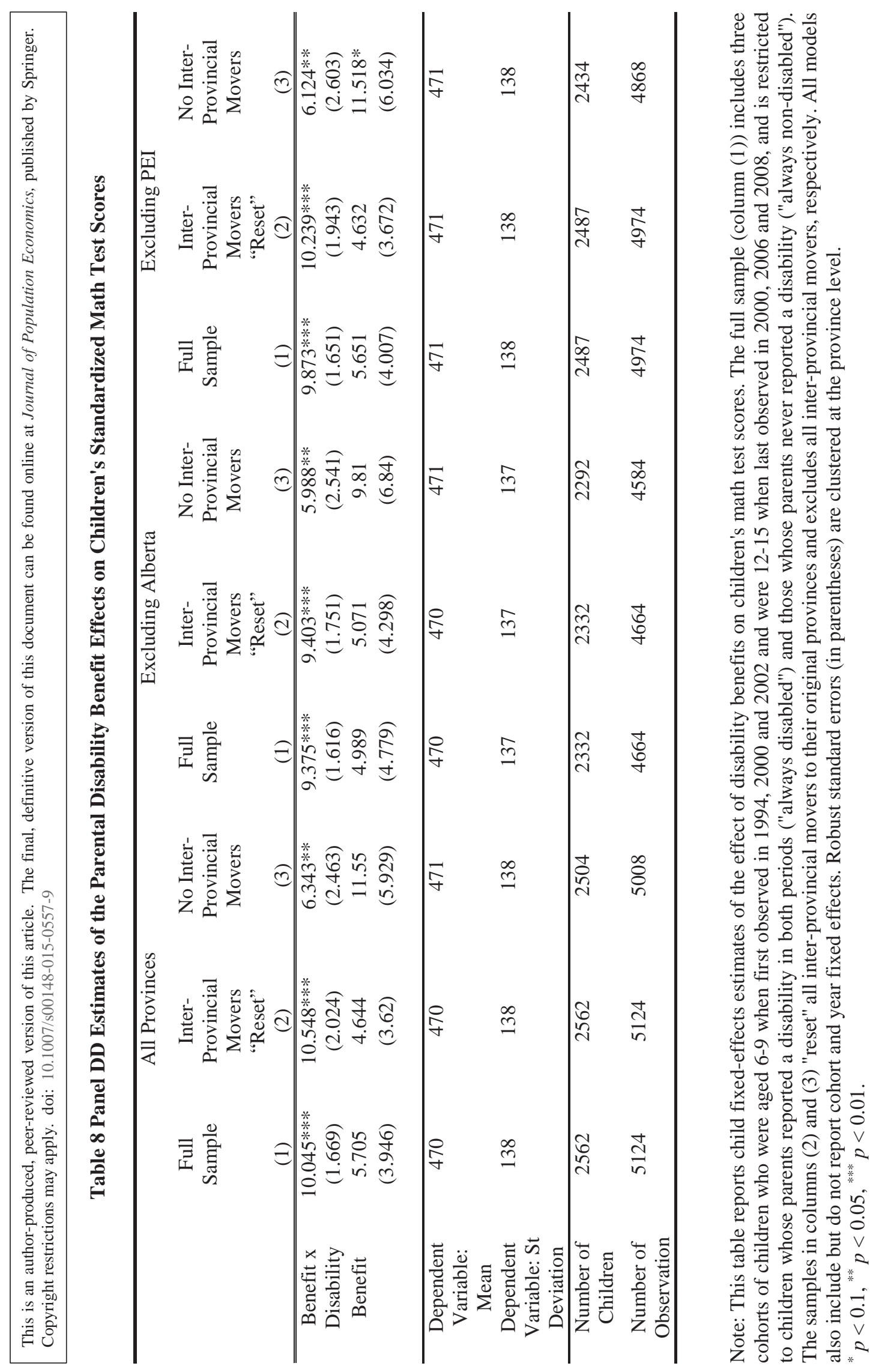




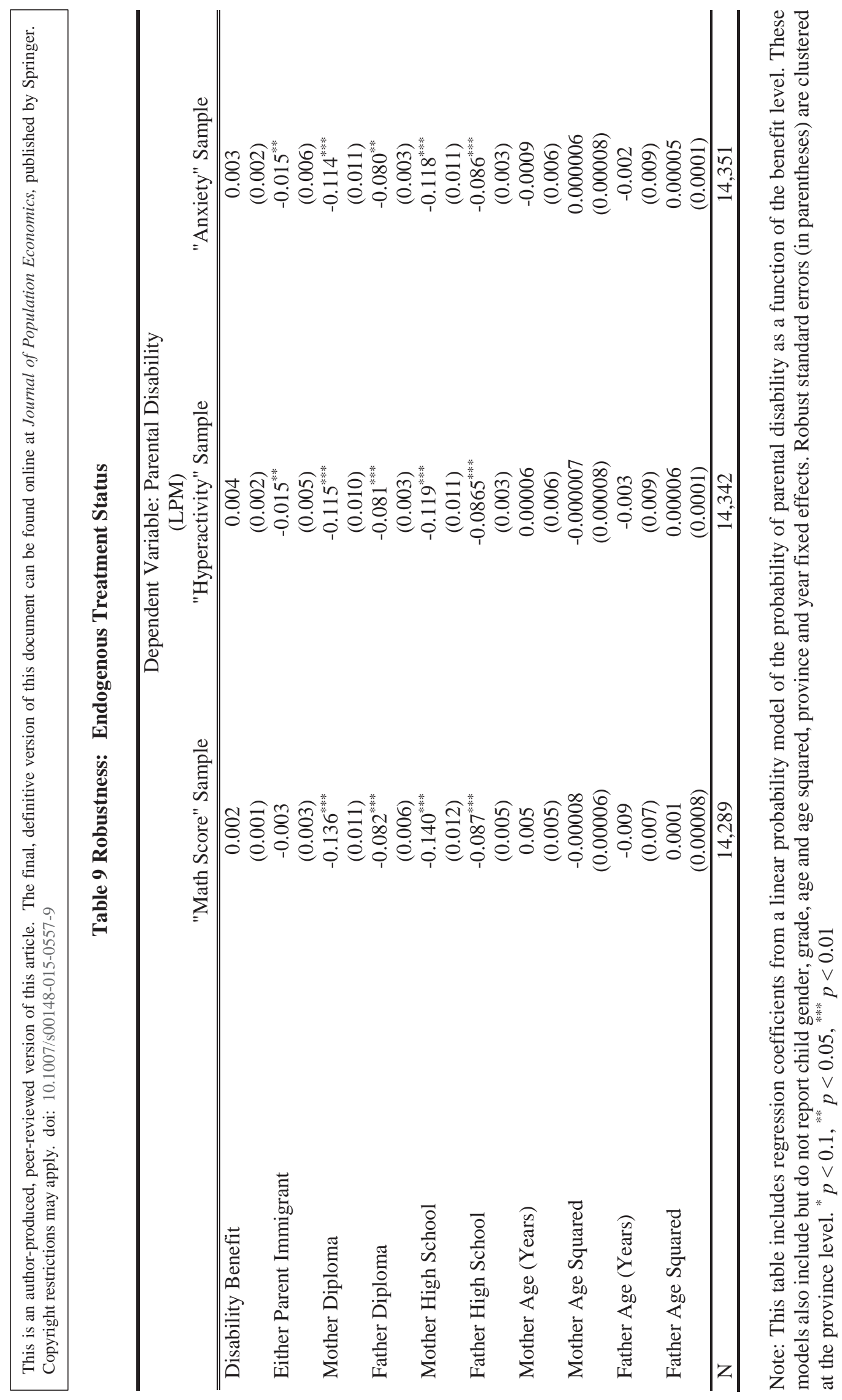




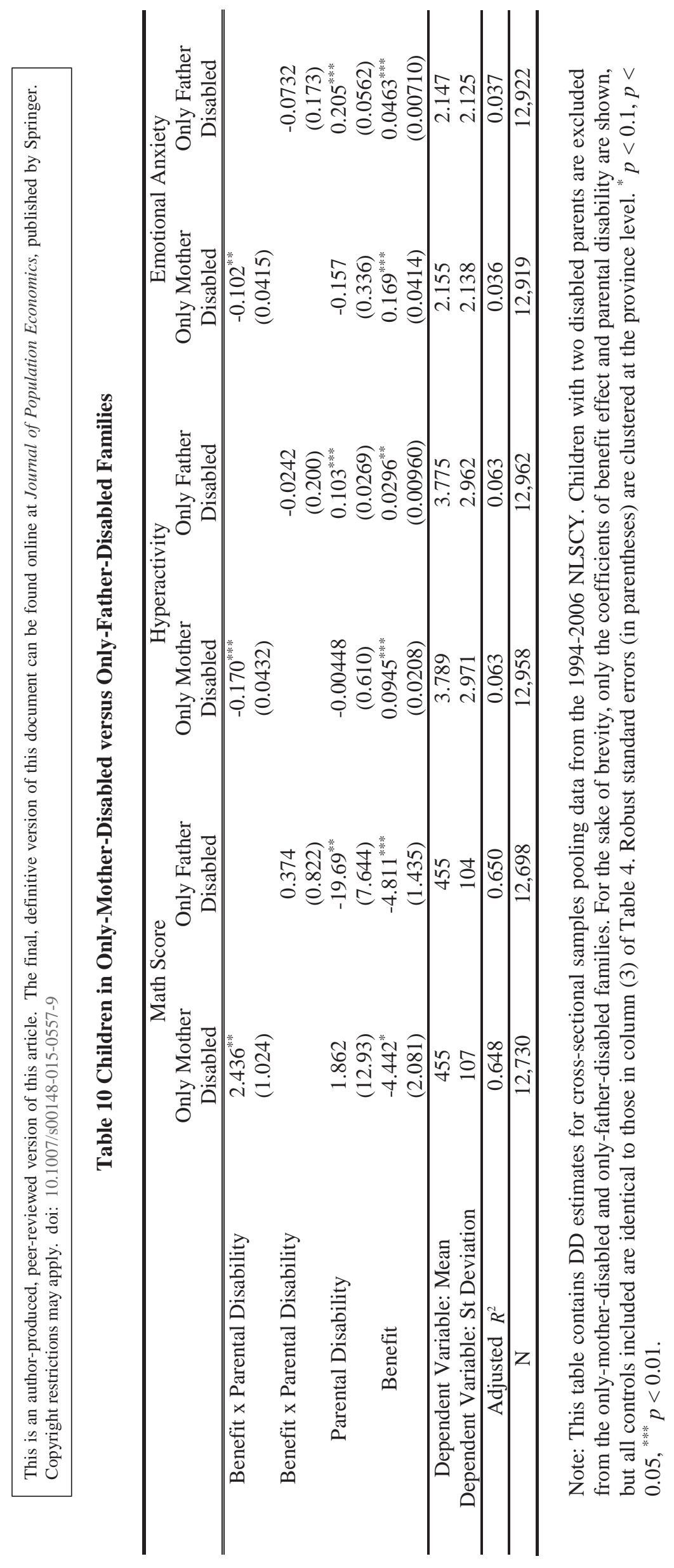




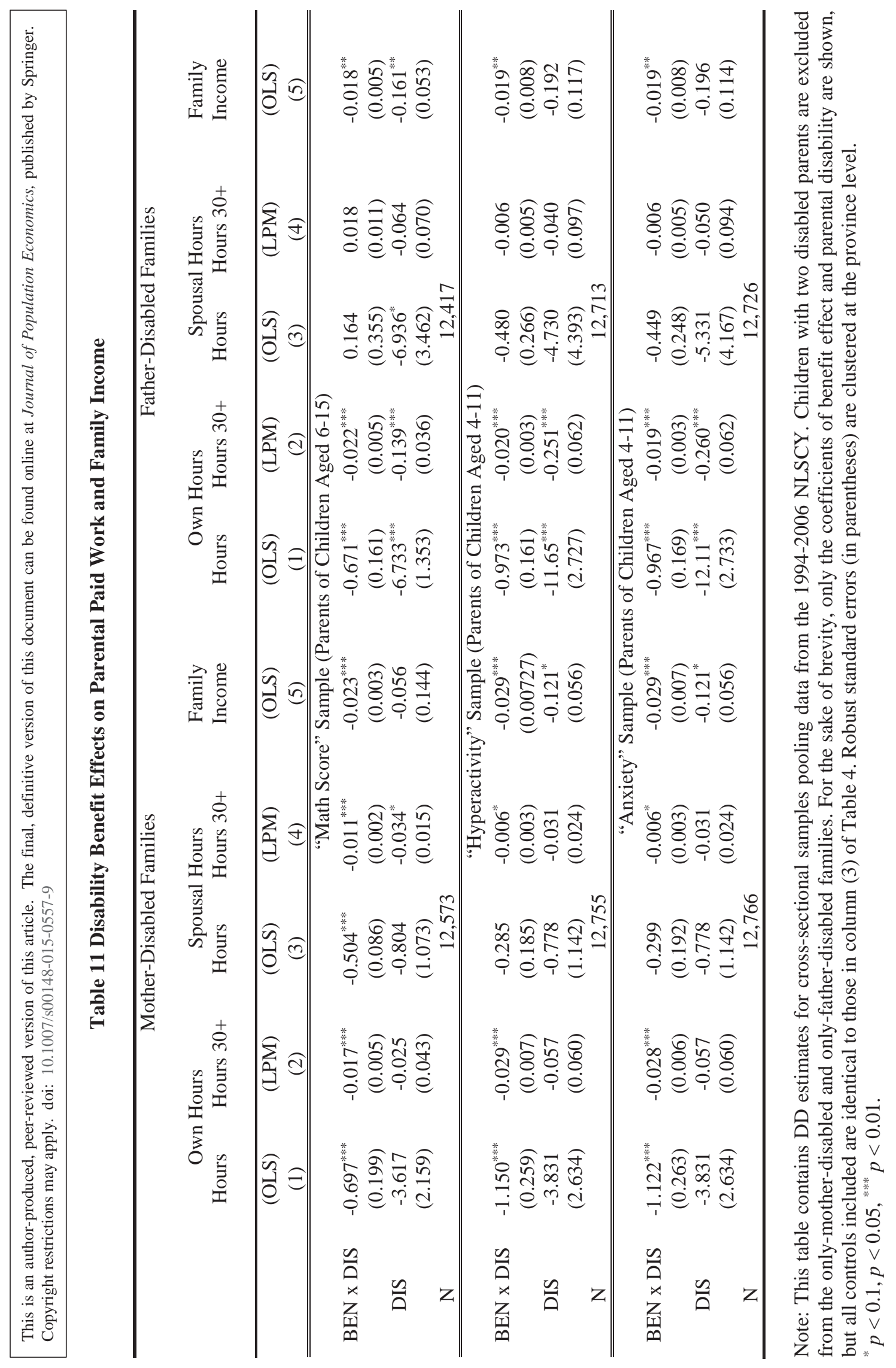




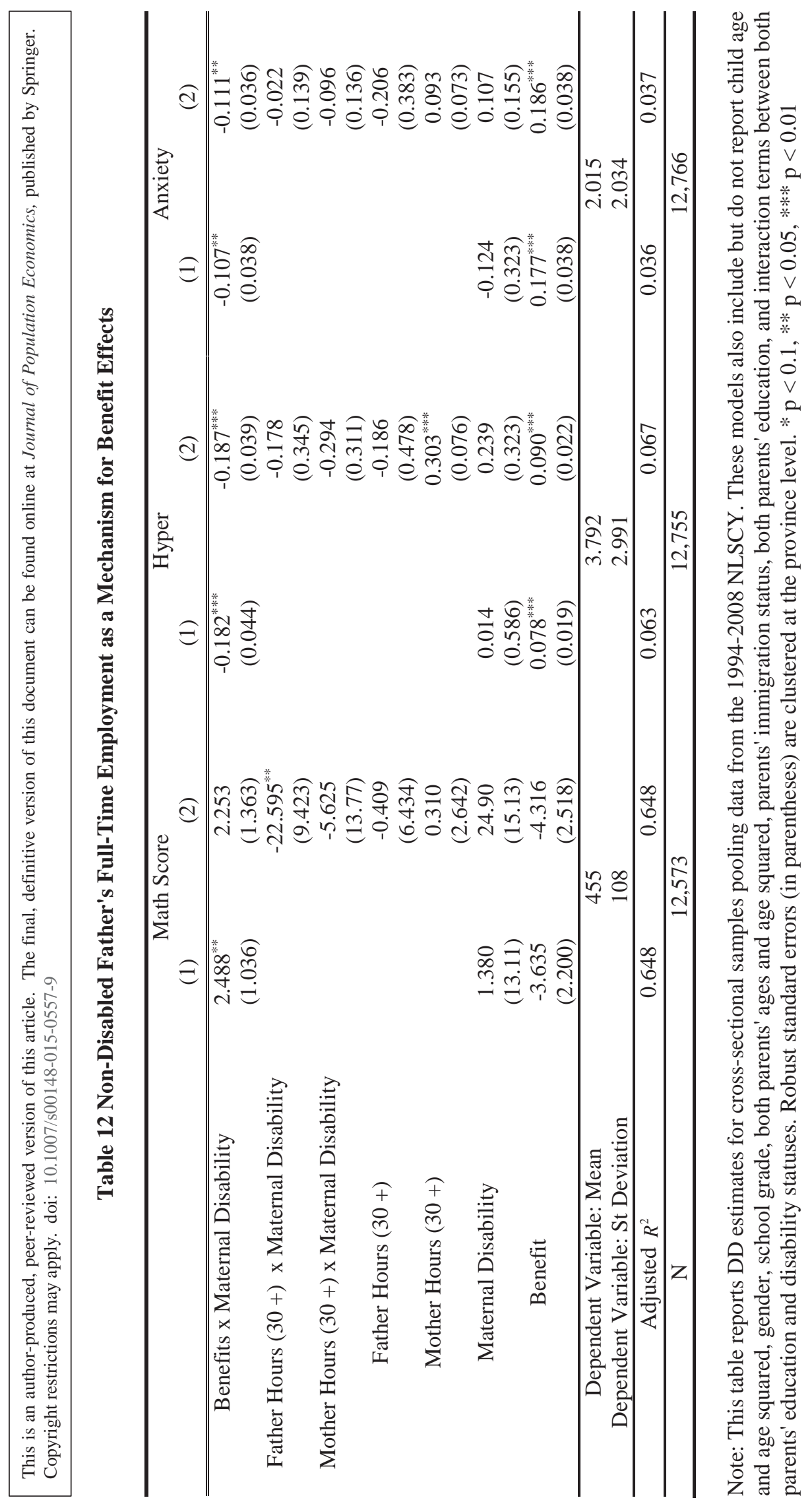


This is an author-produced, peer-reviewed version of this article. The final, definitive version of this document can be found online at Journal of Population Economics, published by Springer. Copyright restrictions may apply. doi: 10.1007/s00148-015-0557-9

\section{Acknowledgments}

We gratefully acknowledge many insightful comments and suggestions by the anonymous reviewers, and scholarship support from Dalhousie University and the Canadian Labour Market and Skills Researcher Network (CLSRN). NSLCY data were accessed through the Atlantic Research Data Centre; we thank Heather Hobson for vetting our output.

\section{Conflict of Interest}

The authors declare that they have no conflict of interest.

\section{References}

Alessandri SM (1992) Effects of Maternal Work Status in Single-Parent Families on Children's Perception of Self and Family and School Achievement. J Exp Child Psychol 54(3): 417-433

Akerlof, GA Kranton RE (2000) Economics and Identity. Q J Econ: 715-753

Avery RC Hogan DP (2006) Family Configurations of Disability in the 2000 Census. Conference presentation at the annual meeting of the Population Association of America

Beauregard, Line, and Luc Noreau (2009). Spouses of Persons with Spinal Cord Injury: Impact and Coping. Brit J Soc Work: bcp140

Becker GS Tomes N (1986) Human Capital and the Rise and Fall of Families. J Labor Econ: S1-S39

Berger MC (1983) Labor Supply and Spouse's Health: The Effects of Illness, Disability, and Mortality. Soc Sci Quart 64(3): 494-509

Berger MC Fleisher BM (1984) Husband's Health and Wife's Labor Supply. J Health Econ 3(1): 63-75

Blau DM (1999) The Effect of Income on Child Development. Rev Econ Stat 81(2): 261-276

Bound J Burkhauser RV (1999) Economic Analysis of Transfer Programs Targeted on People with Disabilities. Handbook of Labor Economics 3: 3417-3528

Bratti M Mendola M (2014) Parental Health and Child Schooling. J Health Econ 35: 94-108

Brooks-Gunn J Duncan GJ (1997) The Effects of Poverty on Children. Future Child: 55-71

Burton P Chen K Lethbridge L Phipps S (2014) Child Health and Parental Paid Work. Rev Econ Househ 5:1-24

Burton P Lethbridge L Phipps S (2008) Children with Disabilities and Chronic Conditions and Longer-Term Parental Health. J Socio Econ 37(3): 1168-1186

Cameron SV Heckman JJ (1998) Life Cycle Schooling and Dynamic Selection Bias: Models and Evidence for Five Cohorts of American Males. J Polit Econ 106(2): 262-333

Campolieti M (2004) Disability Insurance Benefits and Labor Supply: Some Additional Evidence. J Labor Econ 22(4): 863-889

Campolieti M Gomez R Gunderson M (2009) Volunteering, Income Support Programs and Persons with Disabilities. Ind Relat 64(2): 189-208

Chen K Fortin N Phipps S (2015) Young In Class: Implications for Inattentive/Hyperactive Behavior of Canadian Boys And Girls. Can J Econ: Forthcoming

Coile C (2004) Retirement Incentives and Couples' Retirement Decisions. Top Econ Anal Policy 4(1)

Cunha F Heckman JJ Schennach SM (2010) Estimating the Technology of Cognitive and Noncognitive Skill Formation. Econometrica 78(3): 883-931

Currie J (1998) The Effect of Welfare on Child Outcomes: What We Know and What We Need to Know. Northwestern University/University of Chicago Joint Center for Poverty Research. http://econpapers.repec.org/paper/wopjopovw/26.htm. Accessed 1 April, 2014

Currie J (2008) Healthy, Wealthy, and Wise: Socioeconomic Status, Poor Health In Childhood, and Human Capital Development. National Bureau of Economic Research Working Paper No. 13987. http://www.nber.org/papers/w13987. Accessed 1 April, 2014

Currie J (2011) Inequality at birth: Some causes and consequences. No. w16798. National Bureau of Economic Research. http://www.nber.org/papers/w16798. Accessed 1 April, 2014

Currie J Almond D (2011) Human Capital Development before Age Five. Handbook of Labor Economics 4: 13151486

Currie J Stabile M (2003) Socioeconomic Status and Child health: Why is the Relationship Stronger for Older Children? Am Econ Rev 93: 1813-1823 
This is an author-produced, peer-reviewed version of this article. The final, definitive version of this document can be found online at Journal of Population Economics, published by Springer. Copyright restrictions may apply. doi: 10.1007/s00148-015-0557-9

Curtis LJ Dooley MD Lipman EL Feeny DH (2001) The Role of Permanent Income and Family Structure in the Determination of Child Health in Canada. Health Econ 10(4): 287-302

Curtis L Phipps S (2000) Economic Resources and Children's Health and Success at School: An Analysis with the National Longitudinal Survey of Children and Youth. Applied Research Branch, Human Resources Development Canada No. W-01-1-4E. http://publications.gc.ca/site/archiveearchived.html?url=http://publications.gc.ca/collections/collection_2012/rhdcc-hrsdc/MP32-28-01-1-4eng.pdf. Accessed 1 April, 2014

Dooley M Stewart J (2004) Family Income and Child Outcomes in Canada. Can J Econ 37(4): 898-917

Galarneau D Radulescu M (2009) Employment among the Disabled. Perspectives on Labour and Income 10(5): 515

Gallipoli G Turner L (2009) Household Responses to Individual Shocks: Disability and Labor Supply. Nota di lavoro//Fondazione Eni Enrico Mattei: Global challenges No. 97.2009. http://www.econstor.eu/handle/10419/53342. Accessed 1 April, 2014

Gordon PA Perrone KM (2004) When Spouses Become Caregivers: Counseling Implications for Younger Couples. J Rehabil 70(2)

Haveman R Wolfe B (1995) The Determinants of Children's Attainments: A Review of Methods and Findings. J Econ Lit: 1829-1878

Haveman R Wolfe B (2000) The Economics of Disability and Disability Policy. Handbook of Health Economics 1: 995-1051

Hogan DP Shandra CL Msall ME (2007) Family Developmental Risk Factors among Adolescents with Disabilities and Children of Parents with Disabilities. J Adolescence 30(6): 1001-1019

Human Resources and Social Development Canada (2009). Advancing the Inclusion of People with Disabilities 2009. http://www.esdc.gc.ca/eng/disability/arc/federal_report2009/fdr_2009.pdf Accessed 1 Nov, 2014

Lefebvre P Merrigan P Verstraete M (2008) The Effects of School Quality and Family Functioning on Youth Math Scores: A Canadian Longitudinal Analysis. Cahier de recherche/Working Paper 8: 22. http://papers.ssrn.com/sol3/papers.cfm?abstract_id=1266686. Accessed 1 April, 2014

Lethbridge L Phipps S (2006) Income and the Outcomes of Children. Statistics Canada Analytical Studies Branch Research Paper Series 2006281e. http://www.publications.gc.ca/site/archiveearchived.html?url=http://www.publications.gc.ca/Collection/Statcan/11F0019MIE/11F0019MIE2006281.p df. Accessed 1 April, 2014

Lundberg SJ Pollak RA Wales TJ (1997) Do Husbands and Wives Pool Their Resources? Evidence from the United Kingdom Child Benefit. J Hum Resour: 463-480

Mann C Dieppe P (2006) Different Patterns of Illness-Related Interaction in Couples Coping with Rheumatoid Arthritis. Arthrit Care Res 55.2: 279-286

Mayer SE (1997) What Money Can't Buy: Family Income and Children's Life Chances. Harvard University Press

Mayer SE Jencks C (1993) Recent Trends in Economic Inequality in the United States: Income Vs. Expenditures Vs. Material Well-Being. In: Popademitrious D and Wolff E (eds) Poverty and Prosperity in the USA in the Late Twentieth Century. Popademitrious Press, London

Miller AR Zhang L (2009) The Effects of Welfare Reform on the Academic Performance of Children in LowIncome Households. J Policy Anal Manag 28(4): 577-599

Milligan K (2005) Subsidizing the Stork: New Evidence on Tax Incentives and Fertility. Rev Econ Stat 87.3: 539555 Milligan K Stabile M (2011) Do Child Tax Benefits Affect the Well-Being of Children? Evidence from Canadian Child Benefit Expansions. Am Econ J: Econ Policy 3(3): 175-205

Moffitt R (1990) The Effect of the US Welfare System on Marital Status. J Public Econ 41.1: 101-124

Moffitt R (1992) Incentive Effects of the US Welfare System: A Review. J Econ Lit: 1-61

Mont D Cuong N (2013) Does Parental Disability Matter to Child Education? Evidence from Vietnam. World Dev 48: 88-107

Moore KA Driscoll AK (1997) Low-Wage Maternal Employment and Outcomes for Children: A Study. Future Child: $122-127$

Morefield B (2010) Parental Health Events and Children's Skill Development. University of North Carolina at Greensboro Department of Economics Working Papers 10-11. http://econpapers.repec.org/paper/risuncgec/2010_5f011.htm. Accessed 1 April, 2014

Morefield B Mühlenweg AM Westermaier F (2011) Impacts of Parental Health on Children's Development of Personality Traits and Problem Behavior: Evidence from Parental Health Shocks. ZEW Discussion Papers No. 11-049. http://www.econstor.eu/handle/10419/48874. Accessed 1 April, 2014 
This is an author-produced, peer-reviewed version of this article. The final, definitive version of this document can be found online at Journal of Population Economics, published by Springer. Copyright restrictions may apply. doi: 10.1007/s00148-015-0557-9

Morris P Michalopoulos C (2000) The Self-Sufficiency Project At 36 Months: Effects on Children of a Program that Increased Parental Employment and Income. Applied Research Branch, Human Resources Development Canada. http://eric.ed.gov/?id=ED447255. Accessed 2 May, 2015

Phipps S Burton P (1998) What's Mine is Yours? The Influence of Male and Female Incomes on Patterns of Household Expenditure. Economica 65(260): 599-613

Preston P (2012) Parents with Disabilities. International Encyclopedia of Rehabilitation. http://cirrie.buffalo.edu/encyclopedia/en/article/36/ Accessed 1 Nov, 2014

Prince M (2008) Bold Feasibilities: A New Policy Social Architecture for Canadians with Disabilities. http://web.uvic.ca/spp/people/faculty/documents/boldfeasibillites.pdf Accessed 25 April, 2013

Ruhm CJ (2004) Parental Employment and Child Cognitive Development. J Hum Resour 39.1: 155-192

Strohschein L (2005) Household Income Histories and Child Mental Health Trajectories. J Health Soc Behav 46 (4): 359-375

Todd PE Wolpin KI (2007) The Production of Cognitive Achievement in Children: Home, School, and Racial Test Score Gaps. J Hum Capital 1(1): 91-136

Woolley F (2004) Why Pay Child Benefits to Mothers? Can Public Pol: 47-69 
This is an author-produced, peer-reviewed version of this article. The final, definitive version of this document can be found online at Journal of Population Economics, published by Springer. Copyright restrictions may apply. doi: 10.1007/s00148-015-0557-9

\section{Appendix Table 1 Disability Designations in Ten Disability Benefit Programs}

\begin{tabular}{|c|c|}
\hline $\begin{array}{c}\text { Province/Disability } \\
\text { Benefit Programs }\end{array}$ & Disability Designation \\
\hline $\begin{array}{l}\text { NL }^{46} \text { (Income Support } \\
\text { Program) }\end{array}$ & $\begin{array}{l}\text { A person who, because of a persistent and permanent physical, sensory, speech, } \\
\text { communication, psychological, psychiatric, developmental or other disability, } \\
\text { demonstrates significant challenges in accessing education, training, or employment. }\end{array}$ \\
\hline $\begin{array}{l}\text { PEI }^{47} \text { (Social Assistance } \\
\text { Program) }\end{array}$ & A person in need "who has an ongoing intellectual, mental or physical impairment”. \\
\hline $\begin{array}{l}\mathrm{NS}^{48} \text { (Employment } \\
\text { Support and Income } \\
\text { Assistance) }\end{array}$ & $\begin{array}{c}\text { Refers to severe and persistent restriction or impairment that results in an inability to } \\
\text { perform an activity in the range or within the range considered normal for someone } \\
\text { of the same age, gender, and culture. It describes a functional limitation (versus a } \\
\text { diagnosis) and is ongoing in nature. }\end{array}$ \\
\hline $\begin{array}{l}\text { NB }{ }^{49} \text { (Social Assistance } \\
\text { Program) }\end{array}$ & $\begin{array}{l}\text { The Medical Advisory Board considers an individual for certification (of disability) } \\
\text { who suffers from a major physiological, anatomical, or psychological impairment, } \\
\text { which severely limits the individual in normal living activities, and which is likely to } \\
\text { continue indefinitely without substantial improvement (i.e. totally and permanently } \\
\text { disabled). }\end{array}$ \\
\hline $\begin{array}{l}\text { Quebec }^{50} \text { (Social } \\
\text { Solidarity Program) }\end{array}$ & $\begin{array}{l}\text { A person who, because of a persistent and permanent physical, sensory, speech, } \\
\text { communication, psychological, psychiatric, developmental or other disability, } \\
\text { demonstrates significant challenges in accessing education, training, or employment. }\end{array}$ \\
\hline $\begin{array}{l}\mathrm{ON}^{51} \text { (Ontario Disability } \\
\text { Support Program) }\end{array}$ & $\begin{array}{l}\text { A person with a disability is defined as a person who has a substantial physical or } \\
\text { mental impairment that is continuous or recurrent and is expected to last one year or } \\
\text { more. The impairment must result in a substantial restriction in one or more activities } \\
\text { of daily living (ability to attend to personal care, function in the community or } \\
\text { function in a workplace), taking into account the person's age, level of education and } \\
\text { employment experience/work history. }\end{array}$ \\
\hline $\begin{array}{l}\mathrm{MB}^{52} \text { (Employment and } \\
\text { Income Assistance) }\end{array}$ & $\begin{array}{l}\text { (A person who suffers from) physical or mental ill health, or physical or mental } \\
\text { incapacity or disorder that is likely to continue more than } 90 \text { days is unable to earn } \\
\text { income to meet basic necessities or unable to care for themselves. }\end{array}$ \\
\hline $\begin{array}{l}\text { SK }^{53} \text { (Saskatchewan } \\
\text { Assistance Program) }\end{array}$ & $\begin{array}{c}\text { Clients with a disability are those whose employment or training capabilities are } \\
\text { limited and no change is expected within one year. }\end{array}$ \\
\hline $\begin{array}{l}\mathrm{AB}^{54} \text { (Assured Income } \\
\text { for the Severely } \\
\text { Handicapped) }\end{array}$ & $\begin{array}{l}\text { Applicants and clients must have a severe handicap that substantially limits their } \\
\text { ability to earn a living; and is likely to remain permanent. There is no training, } \\
\text { medical treatment or therapy that would improve the person's ability to earn a living. }\end{array}$ \\
\hline $\begin{array}{l}\mathrm{BC}^{55} \text { (BC Employment } \\
\text { and Assistance Program) }\end{array}$ & $\begin{array}{l}\text { Refers to cases which include a person } 18 \text { years of age or over with a severe mental } \\
\text { or physical impairment, which restricts the person`s ability to perform daily living } \\
\text { activities. The person must require an assistive device, the help or supervision of } \\
\text { another person, or the services of an assistance animal to perform daily living } \\
\text { activities. }\end{array}$ \\
\hline
\end{tabular}

${ }^{46}$ NL: Income and Employment Support Regulations. www.hrle.gov.nl.ca/hrle

${ }^{47}$ PEI: Social Assistance Policy Manual http://www.gov.pe.ca/sss/index.php3?number=1028464\&lang=E

${ }^{48}$ NS: http://www.gov.ns.ca/coms/disabilities/documents/GlossaryofTerms.html

${ }^{49}$ NB: Social Assistance Policy Manual. http://www.gnb.ca/0017/Policy\%20Manual/POL-E/policy1.htm\#blind

${ }^{50}$ Quebec: Individual and Family Assistance Act. http://www.mess.gouv.qc.ca/solidarite-sociale/programmesmesures/assistance-emploi/index_en.asp

${ }^{51}$ Ontario: Income Support Directives.

http://www.mcss.gov.on.ca/en/mcss/programs/social/directives/ODSP_incomesupport.aspx

${ }^{52}$ MB: Income Assistance for Persons with Disabilities. http://www.gov.mb.ca/fs/pwd/iapd.html\#content

${ }^{53}$ SK: SAP Policy Manual. http://www.socialservices.gov.sk.ca/SAP-policy-manual.pdf. In addition, a separate disability support program, Saskatchewan Assured Income for Disability (SAID) was initiated since 2009

${ }^{54}$ AB: AISH Policy Manual.

http://www.seniors.alberta.ca/aish/PolicyManual/Policy/Eligibility/Eligibility_Criteria.htm

${ }^{55}$ BC: Persons with disabilities. http://www.hsd.gov.bc.ca/factsheets/2004/pwd.htm 
This is an author-produced, peer-reviewed version of this article. The final, definitive version of this document can be found online at Journal of Population Economics, published by Springer. Copyright restrictions may apply. doi: 10.1007/s00148-015-0557-9

\section{Appendix Table 2 Number of Recipients, Cases and Disability Benefit Level (Ontario Disability Support Program)}

\begin{tabular}{cccccc}
\hline & 2000 & 2002 & 2004 & 2006 & 2008 \\
\hline \hline Number of Recipients & 268,100 & 271,600 & 275,700 & 287800 & 315,700 \\
Number of Cases & 189,100 & 192,300 & 197,500 & 208100 & 228,900 \\
Benefit Level (2008 Constant Dollars) & 14,101 & 13,299 & 12,693 & 12,497 & 12,382 \\
\hline
\end{tabular}

Note: The number of recipients and cases for Ontario Disability Support Program (ODSP) are collected from Social Assistance Statistics Report (2008) and Welfare Incomes (1999-2008), respectively. All benefits are converted into 2008 dollars using provincial seasonally adjusted Consumer Price Index (2011basket content) from Statistics Canada's CANSIM (database) Table 326-0021: http://www5.statcan.gc.ca/cansim/home-accueil?lang=eng, accessed 4 April, 2014.

Appendix Table 3 Associations between Parental Disability and Child Outcomes by Functional Domains

\begin{tabular}{|c|c|c|c|c|c|}
\hline & $\begin{array}{l}\text { Limited at: } \\
\text { Home }\end{array}$ & $\begin{array}{l}\text { Limited at: } \\
\text { Caring for } \\
\text { Children }\end{array}$ & $\begin{array}{l}\text { Limited at: } \\
\text { Work/School }\end{array}$ & $\begin{array}{l}\text { Limited at: } \\
\text { Transportation/Leisure/Other }\end{array}$ & $\mathrm{N}$ \\
\hline Math Score & $\begin{array}{c}-7.383 * * * \\
(2.637)\end{array}$ & $\begin{array}{c}-8.988 * * * \\
(3.257)\end{array}$ & $\begin{array}{c}-7.429 * * * \\
(2.832)\end{array}$ & $\begin{array}{l}-3.423 \\
(2.516)\end{array}$ & 14,289 \\
\hline $\begin{array}{l}\text { Hyperactivity } \\
\text { Symptoms }\end{array}$ & $\begin{array}{c}0.439 * * * \\
(0.133)\end{array}$ & $\begin{array}{l}0.368^{*} \\
(0.197)\end{array}$ & $\begin{array}{c}0.318^{* *} \\
(0.123)\end{array}$ & $\begin{array}{c}0.534^{* * * *} \\
(0.120)\end{array}$ & 14,342 \\
\hline $\begin{array}{l}\text { Emotional } \\
\text { Anxiety }\end{array}$ & $\begin{array}{c}0.298 * * * \\
(0.091)\end{array}$ & $\begin{array}{c}0.337 * * * \\
(0.121)\end{array}$ & $\begin{array}{l}0.257 \\
(0.093)\end{array}$ & $\begin{array}{c}0.375 * * * \\
(0.090)\end{array}$ & 14,351 \\
\hline
\end{tabular}

Note: The sample consists of non-disabled children aged between 4 and 15 years in two-parent families whose parents were 18 and 65 years of age and did not have any university degree. Estimates reported in this table are the coefficient of parental disability from a regression of each outcome measure on parental disability, the child's gender, age and age squared, grade, and year fixed effects. These estimates thus represent gender- and age-adjusted differences in child outcomes associated with parental disability. Robust standard errors (in parentheses) are clustered at the household level. * $\mathrm{p}<0.1,{ }^{* *} \mathrm{p}<0.05,{ }^{* * *} \mathrm{p}<0.01$. 